\title{
AUGSTI PORAINA OKSĪDU KERAMIKA
}

\author{
VISVALDIS ŠVINKA ${ }^{1 *}$, RUTA ŠVINKA² \\ 1,2 Silikātu materiālu institūts, Materiālzinātņu un lietiškās \\ k̦ìmijas fakultāte, Rīgas Tehniskā universitāte, Latvija
}

Kopsavilkums. Silikātu materiālu institūtā kopš 2004. g. tiek veikti pētījumi par augsttemperatūras augsti porainu oksīdu keramiku, kas iegūta ar koncentrētas oksīdu pulveru suspensijas liešanas paṇēmienu. Poru veidošanās notiek ksīmiskas reakcijas ceḷā starp metāliska alumīnija pulveri un ūdeni bāziskā vidē, kur suspensijas pH ir 9,5-10,8. Tādā veidā netiek emitēts $\mathrm{CO}_{2}$, kas parasti notiek, iegūstot keramikas materiālus ar paaugstinātu porainību.

Laikā kopš 2007. g. sintezēti materiāli un veikti pētījumi vairākās augsttemperatūras oksīdu sistēmās: cirkonija oksīdu saturošā (promocijas darbs, G. Buḷa, Cirkonija oksīdu saturoša augsttemperatūras putu keramika, 2008. g.), korundamullīta sistēmā (promocijas darbs, L. Mahṇicka-Goremikina, Sintēzes apstākḷu un leǵējošu piedevu ietekme uz porainas augsttemperatūras oksīdu keramikas īpašībām un struktūru, 2015. g.), alumīnija oksīda sistēmā ar dažādām piedevām (promocijas darbs, I. Zakse-Tiḷuga. Mullītu veidojošu piedevu ietekme uz porainas alumīnija oksīda keramikas īpašībām, 2015. g.; nepabeigts promocijas darbs A. Butlers, Karstumizturīga filtrējoša keramika; maǵistra darbs, J. Bobrovika, Augsti poraina siltumizolējoša kordierīta keramika). Pētītie materiāli paradzēti, lai izmantotu tos kā siltumizolējošus materiālus dažādām augsttemperatūras siltuma ierīcēm un arī karstumizturīgiem filtriem.

Atslēgas vārdi - alumīnija oksīds, cirkonija oksīds, titāna oksīds, kaolīns, talks, kordierīts, nanopulveri, siltuma izolācija, termiskā trieciena izturība.

\section{Cirkonija oksīdu saturoša augsttemperatūras putu keramika}

Cirkonija oksīdu saturoši augsttemperatūras putu keramikas materiālus ieguva no alumīnija oksīda un kaolīna ar 5-33 \% $\mathrm{ZrO}_{2}$ piedevu. Materiālus ieguva ar koncentrētas suspensijas liešanas metodi. Par poras veidojošu vielu izmantoja metālisku alumīnija pulveri, notika

* Korespondējošais autors.

E-pasts: visvaldis.svinka@rtu.lv 
tā reakcija ar ūdeni bāziskā vidē, izdalot ūden,radi. N,emot vērā $\mathrm{ZrO}_{2}$ modifikāciju maiṇu (monoklīns $\leftrightarrow$ tetragonāls $\leftrightarrow$ kubisks) atkarībā no sintēzes apstākḷiem un tā rezultātā iespējamo īpašību izmaiṇu, darbā izmantoja dažādas $\mathrm{ZrO}_{2}$ saturošas izejvielas: nestabilizēts $\mathrm{ZrO}_{2}$, ar 5,3 \% Y ${ }_{2} \mathrm{O}_{3}$ dal̄ejji stabilizēts $\mathrm{ZrO}_{2}$, ar $8 \% \mathrm{Y}_{2} \mathrm{O}_{3}$ pilnīgi stabilizēts $\mathrm{ZrO}_{2}$, ar $10 \% \mathrm{CeO}_{2}$ stabilizēts $\mathrm{ZrO}_{2}$ un ar $10 \% \mathrm{MgO}$ stabilizēts $\mathrm{ZrO}_{2} . \mathrm{ZrO}_{2}$ satura palielināšana izraisa suspensijas viskozitātes palielināšanos un pH vērtības samazināšanos. Palielinoties suspensijas viskozitātei, materiāla valējā porainība samazinās un veidojas mazāka izmēra poras $(\varnothing<1 \mu \mathrm{m})$. Pēc izžāvēšanas visus paraugus apdedzināja $1600{ }^{\circ} \mathrm{C}$ temperatūrā. Skenējošā elektronu mikroskopija (SEM) parādīja, ka materiālā veidojas ar caurejošiem kanāliem savienotas poras. $\mathrm{ZrO}_{2}$ pulvera graudi izvietojas uz mullita un korunda graudu virsmas (1. att.).

$\mathrm{ZrO}_{2}$ saturošas keramikas apdedzināšanas laikā notiek fāžu pāreja monoklīnais $\mathrm{ZrO}_{2}$ (badeleīts) $\leftrightarrow$ tetragonālais $\mathrm{ZrO}_{2}$, ko pavada materiāla lineāro izmēru maiṇa (sarukums uzkarsējot un izplešanās atdzesējot). Tetragonālā $\mathrm{ZrO}_{2}$ stabilizējošas piedevas ievadīšanas mērķis ir panākt cieto šḳīumu veidošanos apdedzināšanas laikā un saglabāt tetragonālo fāzi materiāla atdzesēšanas laikā. Fāžu pāreju stabilizējošās piedevas samazina lineāro izmēru izmaiṇas, pazemina fāžu pārejas sākuma temperatūru un paplašina fāžu pārejas temperatūras intervālu. Dažādu stabilizējošo piedevu ietekme uz keramikas lineāro izplešanos parādīta 2. att.

Svarīga augsttemperatūras materiālu īpašība ir termiskā trieciena izturība, t. i., materiāla spēja izturēt straujas temperatūras svārstības

a

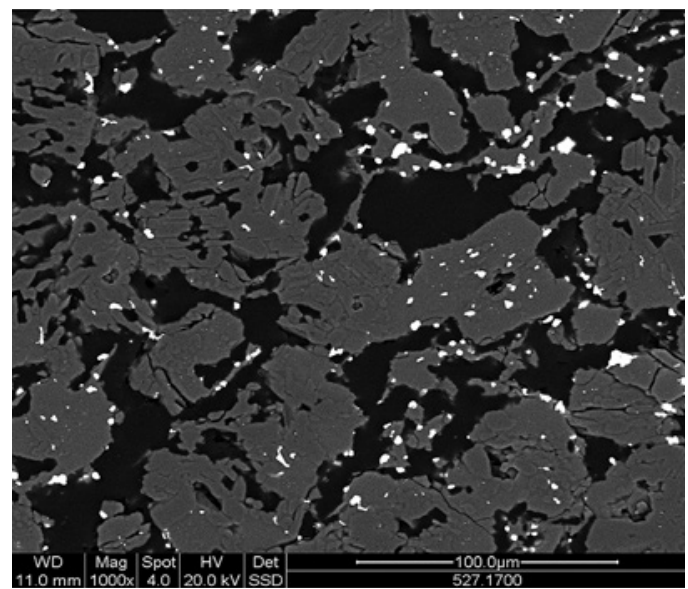

b

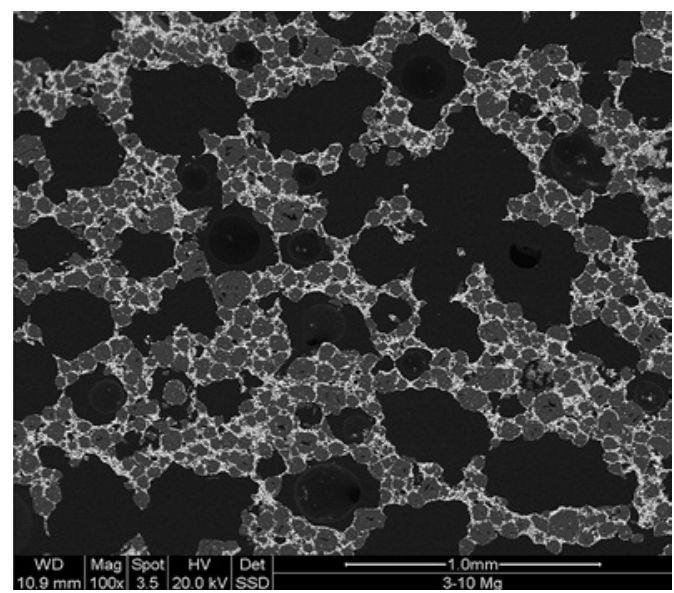

1. att. $\mathrm{ZrO}_{2}$ saturošas augsti porainas korunda-mullīta keramikas SEM attēli: a - nestabilizēts $\mathrm{ZrO}_{2}$; b - ar MgO stabilizētais $\mathrm{ZrO}_{2} 33 \%$. 


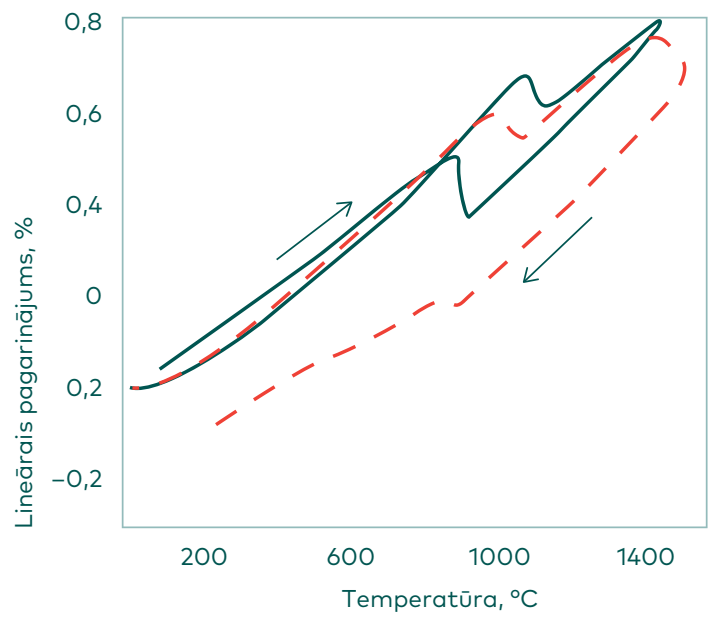

- Nestabilizēts $\mathrm{ZrO}_{2}$

- $\operatorname{Ar} \mathrm{CeO}_{2}$ stabilizēts $\mathrm{ZrO}_{2}$

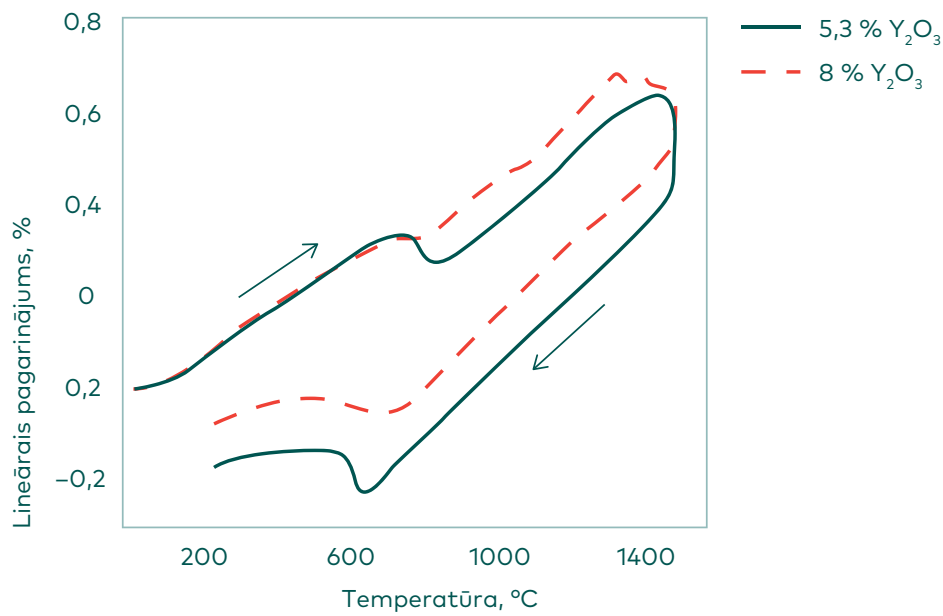

2. att. Lineārā izplešanās korunda-mullīta keramikas paraugiem atkarībā no $\mathrm{ZrO}_{2}$ stabilizējošās piedevas.

nesabrūkot un kritiski nesamazinoties tā mehāniskajai izturībai. Cirkonija oksīdu saturošas augsti porainas keramikas termiskā trieciena izturības noteikšanai izmantota materiālu nesagraujoša akustiska metode. Termiskais cikls ietver materiāla ievietošanu līdz $1200{ }^{\circ} \mathrm{C}$ uzkarsētā krāsnī un tā atdzesēšanu gaisā pēc $1 \mathrm{~h}$ izturēšanas krāsnī. Ar akustisko metodi tiek mērīts materiāla elastības modulis.

Iegūto keramikas materiālu termiskā trieciena izturība, t. i., elastības moduḷ samazināšanās atkārtotu termisko ciklu rezultātā, ir atkarīga galvenokārt no sastāvā esošā $\mathrm{ZrO}_{2}$ satura. Vislielākā termiskā trieciena izturība ir sastāviem ar vidēju (22 \%) $\mathrm{ZrO}_{2}$ saturu, t. i., elastības moduḷa 
samazināšanās 10 termiskās apstrādes ciklu rezultātā nepārsniedz $10 \%$ no sākotnējās elastības moduḷa vērtības.

$\mathrm{ZrO}_{2}$ satura palielināšana samazina keramikas materiāla porainību, un atbilstoši tam materiāla sagrūšanas stiprība un elastības modulis palielinās. Salīdzinot lieces izturību paraugiem ar dažādām $\mathrm{ZrO}_{2}$ struktūru stabilizējošām piedevām, vislielāko lieces stiprības un elastības moduḷa palielinājumu dod ar $10 \% \mathrm{MgO}$ un ar $8 \% \mathrm{Y}_{2} \mathrm{O}_{3}$ cirkonija oksīda tetragonālo modifikāciju stabilizējošās piedevas keramikas sastāvos, neatkarīgi no $\mathrm{ZrO}_{2}$ daudzuma. Vislielākā lieces izturība - $23 \mathrm{MPa}-$ un elastības modulis - $3500 \mathrm{GPa}$ - ir materiāliem ar $\mathrm{ZrO}_{2}$ saturu 33,3 masas $\%$ [1].

\section{II. $\mathrm{TiO}_{2}$ saturoša augsti poraina oksīdu keramika}

Viens no ugunsizturīgajiem materiāliem ar augstu kušanas temperatūru $\left(1860{ }^{\circ} \mathrm{C}\right)$ un mazu termiskās izplešanās koeficientu $\left(\alpha \approx 1,9 \cdot 10^{-6} \mathrm{~K}^{-1}\right)$ ir tialīts jeb alumīnija-titāna oksīds $\left(\mathrm{Al}_{2} \mathrm{TiO}_{5}\right)$. Tialīta lineārās izplešanās koeficients ir 2,5 reizes mazāks kā mullītam. Tas ir būtiski, lai, materiālu izmantojot strauju temperatūras svārstību apstākḷos, nerastos lieli iekšējie spriegumi, kas savukārt var izraisīt plaisu veidošanos un ar laiku sagraut materiālu.

Ir pētīti titāna oksīdu saturoši korunda-mullīta poraini ugunsizturīgi materiāli. Augsti porainas keramikas sintēzei ar šlikera (koncentrētas suspensijas) metodi par izejvielām izmantoja $\gamma$-alumīnija oksīdu un Sedlecas (Čehija) kaolīnu attiecībā 2:1, kā arī $\mathrm{TiO}_{2}$ rutila modifikācijas formā. $\mathrm{TiO}_{2}$ daudzums bija 1,0-13,2 \%. Sintezēta arī otra titāna oksīdu saturoša korunda-mullīta keramikas materiālu sērija ar $\mathrm{TiO}_{2}$ saturu 25-37,5 \% un konstantu kaolīna daudzumu 25 \%. Ūdens saturs suspensijā 28-32 \%. Poru veidošanai nepieciešamais Al pulvera (Schlenk Metallpulver GmbH \& Co, Vācija) daudzums ir 0,1 \% no izejvielu maisījuma svara. $1600{ }^{\circ} \mathrm{C}$ temperatūrā apdedzināto paraugu porainība ir 38-52 \%. Šksietamais blīvums lielāks ir paraugiem ar lielāku titāna oksīda saturu un mazāku kaolīna un alumīnija oksīda saturu, un tas mainās robežās no 0,84 \% līdz 1,34 \%. Augstās temperatūrās izmantojamiem materiāliem l̦oti svarīga īpašîba ir termiskā trieciena izturība. Viens termiskā triecienā cikls ir $20{ }^{\circ} \mathrm{C} \leftrightarrow 1200{ }^{\circ} \mathrm{C}(1 \mathrm{~h}) \leftrightarrow 20^{\circ} \mathrm{C}$. Lielākais elastības modulis ir sastāviem ar lielāku $\mathrm{TiO}_{2}$ saturu. Ja $\mathrm{TiO}_{2}$ saturs ir 13,5 \%, elastības modulis pēc 9 cikliem nedaudz palielinās no $6 \mathrm{līdz} 6,7 \mathrm{GPa}$, bet, ja $\mathrm{TiO}_{2}$ saturs ir $5 \%$, elastības modulis praktiski nemainās, un tas ir 5 GPa. Elastības moduḷa palielināšanas termiskā trieciena iedarbības rezultātā liecina par paraugā esošo mikroplaisu aizvēršanos, tā rezultātā arī uzlabojas elastības modulis. Par materiālā notiekošām pārmaiṇām strauju 


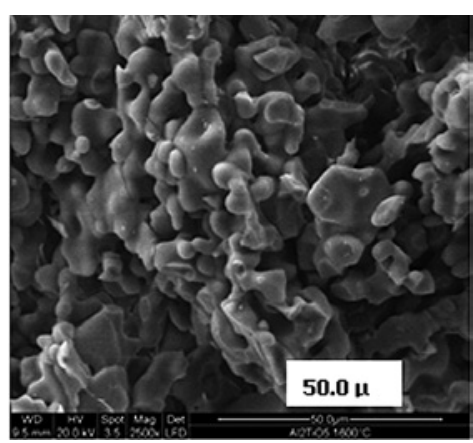

3. att. $1600{ }^{\circ} \mathrm{C}$ temperatūrā apdedzināta tialīta sastāva keramikas mikrofotogrāfija.

temperatūras izmaiṇu rezultātā liecina arī paraugu rentgena staru fāžu analīze pirms un pēc termiskā trieciena. Paraugos pēc termiskā trieciena testiem vairs nav tialīta, bet tā vietā parādās rutils un paraugu krāsa no baltas mainās uz dzeltenīgu, t. i., krāsu, kas raksturīga rutilam, un skenējošā elektronu mikroskopijā redzami noapal̦oti tialīta kristāli (3. att.). Termiskās izplešanās līkne (4. att.) norāda uz orientētu tialīta kristalizāciju paralēli poru tilpuma palielināšanās virzienam. Līdz $200{ }^{\circ} \mathrm{C}$ temperatūrai parauga izplešanās ir negatìva (sarukums). Lineārās izplešanās temperatūras koeficients $30-600{ }^{\circ} \mathrm{C}$ temperatūru intervālā ir l̦oti mazs $0,71 \cdot 10^{-6} \mathrm{~K}^{-1}$. Izvērtējot rentgena staru fāžu analīzes rezultātus (Brucker rentgena staru difraktometrs, Vācija), sastāviem ar lielāko $\mathrm{TiO}_{2}$ saturu (37,5 \%), redzama mullìta difrakcijas līniju nobīde, kas saistīta ar mullìta režǵa parametru izmaiṇu sakarā ar titāna jona saistīšanos mullīta kristāliskajā režgiī (I. tabula).

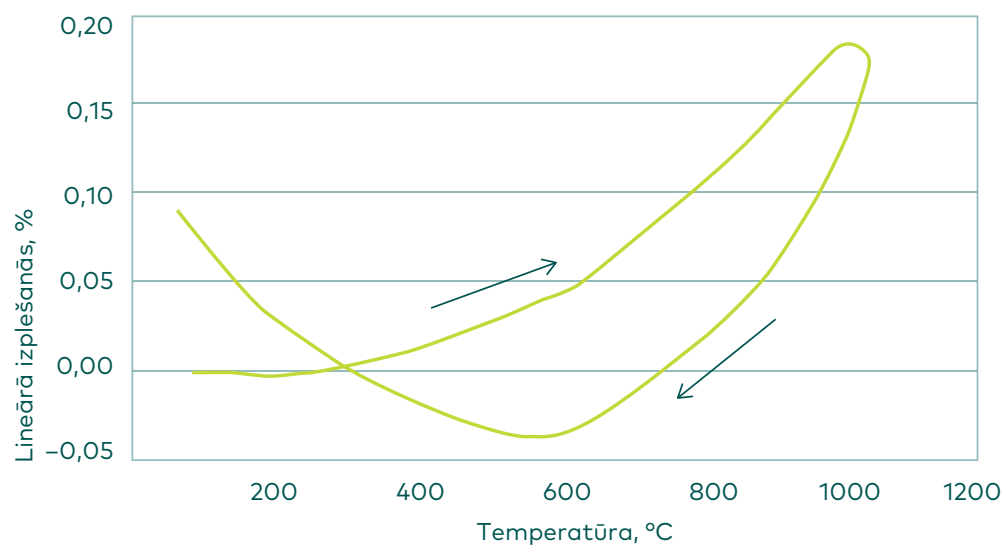

4. att. $1600{ }^{\circ} \mathrm{C}$ temperatūrā apdedzinātas tialīta sastāva keramikas termiskās izplešanās līkne. 
Mullīta kristāliskā režǵa parametru izmaiṇa

\begin{tabular}{ccc}
\hline Režğa parametrs, $\mathrm{nm}$ & Mullïts & Mullīts ar titānu \\
\hline a & 75,46 & 75,45 \\
b & 76,90 & 77,09 \\
c & 28,84 & 28,85 \\
\hline
\end{tabular}

Termiski visstabilākais tialīts ir ķīmiskajam sastāvam atbilstošā keramikas materiālā. Citu kristālisku fāžu klātbūtnē tialīta termiskā stabilitāte samazinās. Termiskā trieciena izturība sintezētajos materiālos ir apmierinoša un ir atkarīga no titāna oksīda daudzuma keramikas materiālā un no materiāla porainības.

\section{Mullīta-korunda augsttemperatūras augsti poraina keramika}

Mullīts ir vienīgā termodinamiski stabilā binārā kristāliskā fāze $\mathrm{SiO}_{2}-\mathrm{Al}_{2} \mathrm{O}_{3}$ sistēmā. Izmantojot alumīnija oksīdu un kaolīnu mullīta sintēzei, kā papildus fāze veidojas arī korunds. Mullīts ir svarīgs dažādu augsttemperatūras tehnologisko procesu nodrošināšanai kā konstrukciju materiāls vai siltumu izolējošs materiāls, ja tas ir ar lielu porainību. Augsti porainu keramikas materiālu iespējams iegūt ar koncentrētas suspensijas liešanas pan̄ēmienu, par poras veidojošu materiālu izmantojot alumīnija pulveri, kas, reagéjot ar ūdeni, izdala ūdeṇradi. Šādā veidā iegūtu materiālu porainība un poru forma mainās atkarībā no izmantotā alumīnija daudzuma. Kā rāda divdimensionālā attēla analīze (Image $C$, Imtronic $\mathrm{GmbH}$, Vācija) un trīsdimensionāla rentgena staru tomogrāfija ( $\mu \mathrm{CT}$ 40, Scanco Medical GmbH, Šveice) poras pārsvarā ir eliptiskas, un poru eliptiskums palielinās, palielinoties materiāla porainībai (mērījumi veikti Erlangenas-Nirnbergas universitātē] [3].

Korunda-mullìta keramikas ugunsizturība ir līdz $1650{ }^{\circ} \mathrm{C}$, bet tās trūkums ir zema termiskā trieciena izturība, t. i., materiāla sabrukšana strauju temperatūras svārstību rezultātā. Straujas temperatūras svārstības rada kritiska lieluma termiskos spriegumus, kas noved pie materiāla mehāniskās izturības samazināšanās un rezultātā pie materiāla destrukcijas. Abu keramiku sastāvā esošās kristāliskās fāzes korunds $\mathrm{Al}_{2} \mathrm{O}_{3}$ un mullīts $3 \mathrm{Al}_{2} \mathrm{O}_{3} \cdot 2 \mathrm{SiO}_{2}$ ir ar atšksirīgiem lineārās izplešanās temperatūras koeficientiem. Korundam tas ir $8,8 \cdot 10^{-6} \mathrm{~K}^{-1}$, bet mullītam tas ir $5,3 \cdot 10^{-6} \mathrm{~K}^{-1}$. Viens no paṇēmieniem kā palielināt termiskā trieciena 
izturību ir ievadīt materiālā tādas izejvielu komponentes, kuras materiāla apdedzināšanas laikā veido kristāliskas fāzes ar lineārās izplešanās koeficientiem, kuru lielumi ir starp pamatfāžu lineārās izplešanās temperatūras koeficientiem. Tomēr, ja iegūstamā materiāla pamatfunkcija ir siltuma izolācija, tad šis faktors ir jānnem vērā. Labas siltuma izolācijas īpašības iespējams saglabāt arī, regulējot porainību un poru izmēru sadalījumu. Tāpat zināma nozīme var būt arī kristālisko fāžu savstarpējam sakārtojumam un kristālu izmēriem.

L. Mahṇickas-Goremikinas promocijas darbā par pamatizejvielām korunda-mullīta keramikas iegūšanai izmantoti $\alpha$ - un $\gamma-\mathrm{Al}_{2} \mathrm{O}_{3}$, kaolīns un amorfs $\mathrm{SiO}_{2}$. Par piedevām keramikas īpašību regulēšanai izmantoti 5 masas\% mikrometra izmēru volframa un magnija oksīdi un ar magniju stabilizēts cirkonija oksīds. Atkarībā no sastāva materiāli apdedzināti $1200-1750{ }^{\circ} \mathrm{C}$ temperatūrās. Darba pamatuzdevums bija iegūt augsti porainu korunda-mullīta keramiku ar iespējami lielāku mullīta saturu tajā (5. att.), panākot iespējami lielāku termiskā trieciena izturību un iespējami zemāku siltuma vadāmības koeficientu. Sastāvos bez piedevām, palielinot kaolīna daudzumu no 10 līdz 30 masas\%, mullīta daudzums paraugos palielinās. $1750^{\circ} \mathrm{C}$ temperatūrā apdedzinātos paraugos, kuru sākotnējā sastāvā bija ievadīti 30 masas\% kaolīna, vienīgā kristāliskā fāze bija mullīts [4]. Šis sastāvs arī tika izmantots kā bāzes sastāvs piedevu ietekmes noskaidrošanai. Mg0 piedeva bāzes sastāvam stipri ietekmē kristālisko fāžu sastāvu [5]. Zemākās temperatūrās līdz $1300{ }^{\circ} \mathrm{C}$ veidojas arī kordierīts. Tikai $1500{ }^{\circ} \mathrm{C}$ apdedzinātos paraugos ar $\mathrm{MgO}$ piedevu mullìts kḷūst par galveno kristālisko fāzi. Sastāvos ar $\mathrm{ZrO}_{2}$ piedevu mullīta veidošanās notiek divējādi: 1) reakcijā starp $\mathrm{Al}_{2} \mathrm{O}_{3}$ un $\mathrm{SiO}_{2}$; 2) caur pārejas savienojumu cirkonu $\left(\mathrm{ZrSiO}_{4}\right)$, tam reagéjot ar $\mathrm{Al}_{2} \mathrm{O}_{3}$ temperatūrās ap $1600^{\circ} \mathrm{C}$. $\mathrm{WO}_{3}$ piedeva bāzes sastāvam ievērojami pazemina mullīta veidošanās temperatūru, un tas kā galvenā kristāliskā

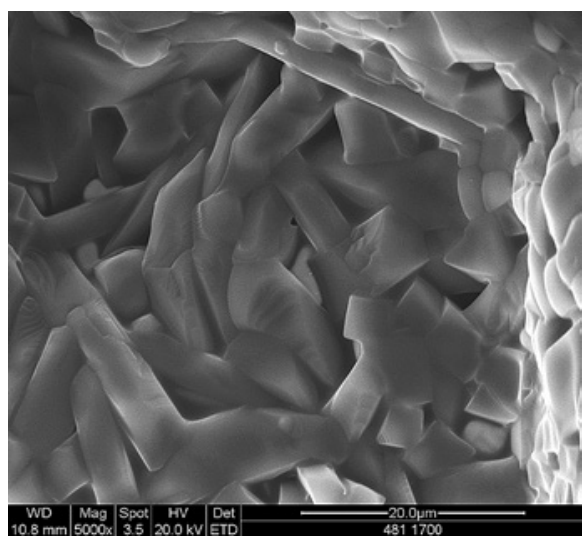

5. att. Mullīta veidošanās starp alumīnija oksīda graudiem. 


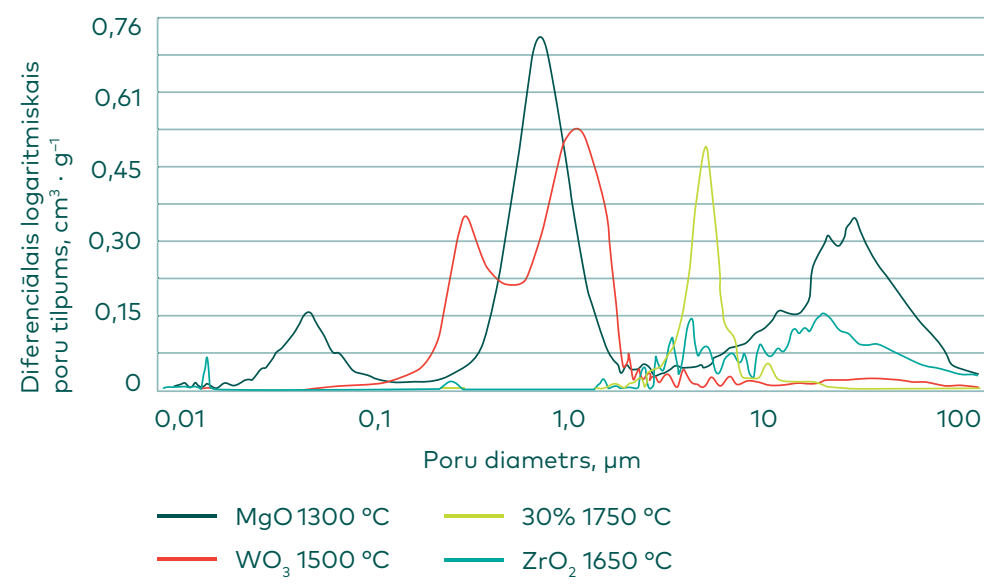

6. att. Dažādās temperatūrās apdedzinātu paraugu bez un ar modificējošām piedevām diferenciālais logaritmiskais poru tilpums.

fāze pastāv jau $1300^{\circ} \mathrm{C}$ apdedzinātos paraugos. Šajos paraugos papildus parādās arī alumīnija volframāts $\mathrm{Al}_{2}(\mathrm{WO})_{3}$. Alumīnija volframāta iespējamā veidošanās notiek uzkarsēšanas procesā, un alumīnija volframāta veidošanās varētu notikt vienlaicīgi ar $\gamma-\mathrm{Al}_{2} \mathrm{O}_{3}$ pāreju par $\alpha-\mathrm{Al}_{2} \mathrm{O}_{3}$, kad alumīnija oksīda reakcijas spēja ir vislielākā.

Piedevas, tāpat kā apdedzināšanas temperatūra, būtiski izmaina materiālu poru struktūru (6. att.). Attēlā apkopoti dzīvsudraba porozimetrijas (PoreMaster 33, Quantachrome Instruments) rezultāti paraugiem bez modificējošām piedevām $\left(30 \% 1750{ }^{\circ} \mathrm{C}\right)$ un ar attiecīgām modificējošām piedevām optimālajās apdedzināšanas temperatūrās. Bāzes sastāvam dominējošais poru tilpums ir ap $20 \mu \mathrm{m}$, bet MgO piedevas gadījumā ir divi dominējošie poru izmēru diapazoni: 1-8 $\mu \mathrm{m}$ un 100-300 $\mu \mathrm{m}$. $\mathrm{ZrO}_{2}$ piedevas gadījumā pārsvarā ir poras ar izmēriem 10-500 $\mu \mathrm{m}$, un to tilpums ir ievērojami mazāks nekā pārējos sastāvos. Savukārt sastāvā ar $\mathrm{WO}_{3}$ piedevu pārsvarā ir poras $0,5-8 \mu \mathrm{m}$ diapazonā.

No materiālu īpašîbu (lieces izturība, lineārā termiskā izplešanās, siltuma vadāmība, termiskā trieciena izturība) viedokḷa modificējošo piedevu loma ir atškirīga. II. tabulā parādīta sakarība starp materiāla porainību pēc porozimetrijas rezultātiem un lieces izturību. Īpašību atkarība no paraugu apdedzināšanas temperatūras atbilst vispārīgām klasiskām sakarībām - paaugstinot apdedzināšanas temperatūru vienas sērijas (piedevas) robežās, materiāla porainība samazinās un mehāniskās īpašîbas (lieces izturība) palielinās.

Tā kā materiālu k̦īmiskais sastāvs ietekmē poru struktūru, tad tā savukārt ietekmē arī visas materiālu īpašības. Viena no svarīgākajām 
legūto paraugu porainība un lieces izturība

\begin{tabular}{|c|c|c|c|c|c|c|c|c|c|c|}
\hline \multirow{2}{*}{$\begin{array}{c}\text { Piedeva } \\
\text { Apdedzināšanas } \\
\text { temperatūra, }{ }^{\circ} \mathrm{C}\end{array}$} & \multicolumn{3}{|c|}{$\begin{array}{c}\text { Bez piedevām, } 30 \% \\
\text { kaolīna }\end{array}$} & \multicolumn{4}{|c|}{$\mathrm{WO}_{3}$} & \multicolumn{2}{|c|}{$\mathrm{MgO}$} & \multirow{2}{*}{$\frac{\mathrm{ZrO}_{2}}{1650}$} \\
\hline & 1650 & 1700 & 1750 & 1200 & 1300 & 1400 & 1500 & 1200 & 1300 & \\
\hline Porainība, \% & 25 & 20 & 14 & 47 & 46 & 43 & 42 & 67 & 62 & 16 \\
\hline $\begin{array}{l}\text { Lieces izturība, } \\
\mathrm{MPa}\end{array}$ & 13 & 31 & 33 & 1 & 8 & 5 & 11 & 0,7 & 1 & 38 \\
\hline
\end{tabular}

tehnoloǵiskajām īpašībām ir paraugu sarukums apdedzināšanas laikā. Šajā ziṇā vislabvēlīgākā ietekme ir $\mathrm{WO}_{3}$, kur $1500{ }^{\circ} \mathrm{C}$ temperatūrā apdedzinātas keramikas sarukums ir 5,6 \%, kamēr $\mathrm{ZrO}_{2}$ vai $\mathrm{MgO}$ saturošas keramikas sarukums šajā temperatūrā sasniedz ap $19 \%$.

Viena un tā paša sastāva paraugu lineārā izplešanās ir atkarīga no sākotnējās apdedzināšanas temperatūras - paaugstinot parauga apdedzināšanas temperatūru, tā relatīvais lineārais pagarinājums samazinās un attiecīgi samazinās arī lineārās izplešanās temperatūras koeficients. Modificējošo piedevu ietekme uz lineāro pagarinājumu (horizontālais dilatometrs $276 / 1600 D$ ) parādīta 7. att. Ar $\mathrm{MgO}$ un $\mathrm{WO}_{3}$ modificētiem

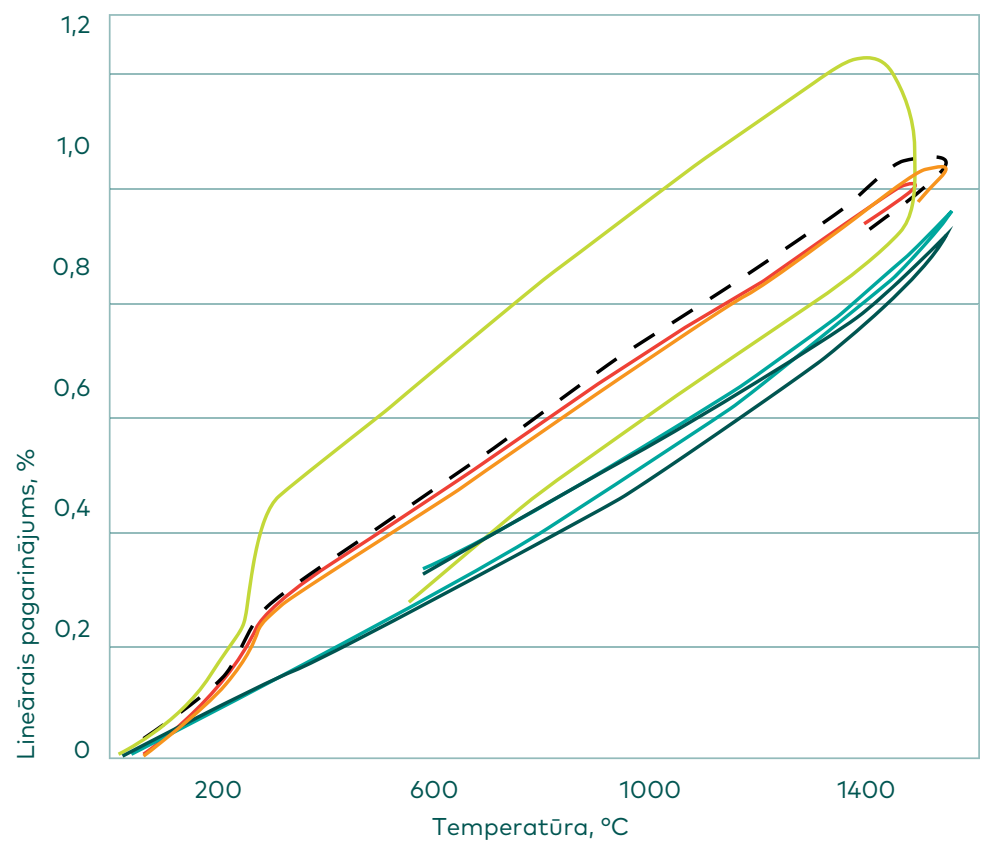

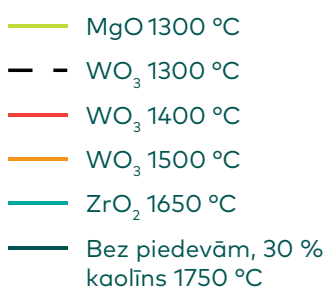

7. att. Bāzes (30\% kaolīns) sastāva keramikas un modificētās keramikas paraugu lineārais pagarinājums. 
keramikas paraugiem temperatūrās ap $200{ }^{\circ} \mathrm{C}$ parādās lēcienveida novirze no linearitātes. Līdzīgi lēcienveidā šajā temperatūrā mainās arī lineārās izplešanās temperatūras koeficients. Šāda novirze saistāma ar paraugos esošā zemtemperatūras $\alpha$-kristobalīta pāreju par augsttemperatūras $\beta$-kristobalītu. Pāreja saistīta ne vien ar struktūras izmainu, bet arī ar tilpuma palielināšanos par 3-5 \%. Mullīta un alumīnija volframāta klātbūtnē, kuriem ir relatīvi neliels lineārās izplešanās temperatūras koeficients, attiecīgi $5,3 \cdot 10^{-6} \mathrm{~K}^{-1}$ un $-1,5 \cdot 10^{-6} \mathrm{~K}^{-1}$, samazina $\alpha \rightarrow \beta$ kristobalīta modifikāciju mainnas efekta lielumu. Savukārt ar MgO modificētiem keramikas paraugiem šāda parādība nav novērojama. Visas piedevas bāzes sastāvam ar $30 \%$ kaolīna palielina šo paraugu lineārās izplešanās temperatūras koeficientu.

Salīdzinot savā starpā piedevu ietekmi uz koeficientu, redzams, ka visvairāk to palielina $\mathrm{MgO}$ piedeva, bet vismazāk $\mathrm{WO}_{3}$ piedeva. $\mathrm{ZrO}_{2}$ šajā salīdzinājumā ieṇem starpstāvokli [6]. Materiāla termiskā trieciena izturība ir atkarīga galvenokārt no tā porainības, poru izmēriem un poru izmēru sadalījuma materiālā. Ķīmiskais sastāvs, t. i., piedevas bāzes sastāvam, netieši ietekmē arī termiskā trieciena izturību, jo tās ietekmē poru izmēru sadalījumu. Termiskā trieciena izturība noteikta ar nesagraujošo akustisko sistēmu Buzz-O-Sonic 5,0, mērot elastības un bīdes moduḷu izmaiṇu pēc termiskās apstrādes cikliem. Elastības moduḷa izmaiṇa atkarībā no termiskās apstrādes ciklu skaita parādīta 8. att. Labāko termiskā trieciena izturību uzrāda $1500{ }^{\circ} \mathrm{C}$ temperatūrā apdedzināti paraugi ar $\mathrm{WO}_{3}$ piedevu bāzes sastāvam. Šiem paraugiem 10 termiskās apstrādes ciklu laikā elastības modulis samazinās nedaudz, salīdzinot ar elastības moduli 11 GPa pirms termiskās apstrādes. Šì sastāva materiālam ir salīdzinoši liela porainība un poras šaurā izmēru diapazonā. Tāpat svarīga

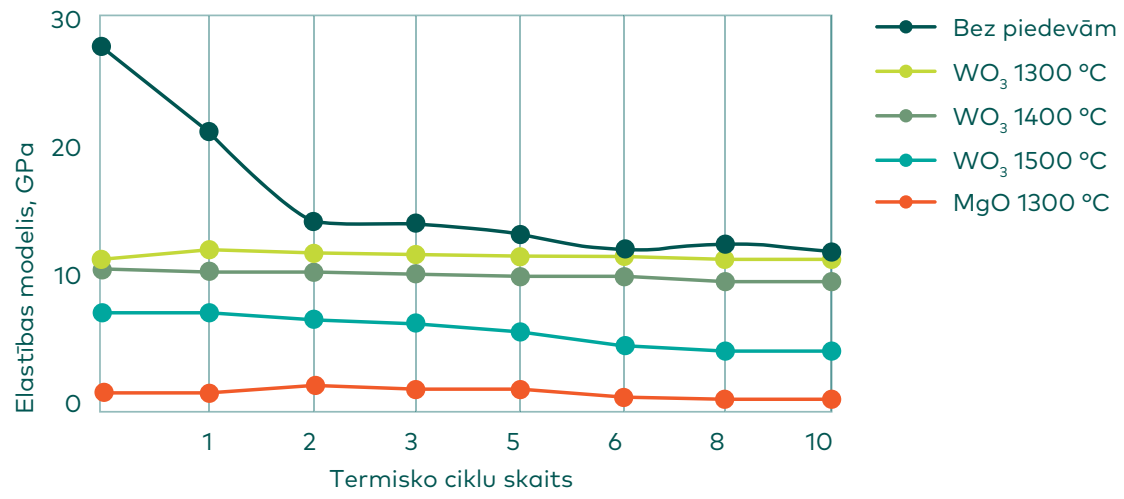

8. att. Elastības moduḷa izmaiṇa atkarībā no termisko ciklu skaita $\left(20^{\circ} \mathrm{C} \rightarrow 1000^{\circ} \mathrm{C} \rightarrow 20^{\circ} \mathrm{C}\right)$ skaita. 
Siltuma vadāmības koeficienta vērtības $25-1000^{\circ} \mathrm{C}$ temperatūru intervāla,$\left(\mathrm{W} \cdot \mathrm{m}^{-1} \cdot \mathrm{K}^{-1}\right)$

\begin{tabular}{cccccccccccc}
\hline \multirow{2}{*}{ Sastāvi } & \multicolumn{10}{c}{ Temperatūras, ${ }^{\circ} \mathrm{C}$} \\
\cline { 2 - 10 } & $\mathbf{2 5}$ & 100 & 200 & $\mathbf{3 0 0}$ & $\mathbf{4 0 0}$ & $\mathbf{5 0 0}$ & $\mathbf{6 0 0}$ & $\mathbf{7 0 0}$ & $\mathbf{8 0 0}$ & $\mathbf{9 0 0}$ & 1000 \\
\hline $\begin{array}{c}\text { Bez piedevām } \\
1750^{\circ} \mathrm{C}\end{array}$ & 2,21 & 2,15 & 2,02 & 1,97 & 1,89 & 1,80 & 1,75 & 1,70 & 1,70 & 1,70 & 1,75 \\
$\mathrm{ZrO}_{2} 1650^{\circ} \mathrm{C}$ & 1,85 & 1,80 & 1,72 & 1,69 & 1,61 & 1,55 & 1,51 & 1,49 & 1,50 & 1,58 & 1,77 \\
$\mathrm{MgO}_{1500}{ }^{\circ} \mathrm{C}$ & 1,79 & 1,75 & 1,70 & 1,65 & 1,60 & 1,55 & 1,51 & 1,51 & 1,55 & 1,59 & 1,60 \\
$\mathrm{WO}_{3} 1500^{\circ} \mathrm{C}$ & 0,93 & 0,91 & 0,90 & 0,86 & 0,83 & 0,80 & 0,79 & 0,78 & 0,80 & 0,86 & 1,02 \\
\hline
\end{tabular}

nozīme termiskā trieciena izturības stabilitātei ir kristālisko fāžu klātbūtne ar atšksirīgiem lineārās izplešanās temperatūras koeficientiem.

Materiālos ar $\mathrm{WO}_{3}$ piedevu papildus veidojas alumīnija volframāts ar negatīvu lineārās izplešanās temperatūras koeficientu $-1,5 \cdot 10^{-6} \mathrm{~K}^{-1}$. Volframa oksīdu saturošā mullīta-korunda keramika veido raksturīgu klastera tipa struktūru, kur klastera vidusdal̦u veido korunds, bet apkārtējo daḷu veido mullīts un alumīnija volframāts. Strauju temperatūras izmaiṇu rezultātā radušies termiskie spriegumi savstarpēji kompensējas, un plaisas neattīstās. Sastāvos bez piedevām un sastāvos ar $\mathrm{MgO}$ un $\mathrm{ZrO}_{2}$ piedevām ir raksturīgas lielākas poras, un to izmēri ir plašā diapazonā, kā arī raksturīgas divas kristāliskās fāzes - korunds un mullīts ar stipri atškirīgiem izplešanās koeficientiem, kas veicina plaisu veidošanos. Iegūtajiem materiāliem noteikta siltuma vadāmība 25-1000 ${ }^{\circ} \mathrm{C}$ temperatūras intervālā (Netzch FLA 457 MicroFlash, Erlangenas-Nirnbergas universitāte, Vācija). Siltuma vadāmības noteikšanai izmantota bāzes sastāva keramika, kas apdedzināta $1750{ }^{\circ} \mathrm{C}$ temperatūrā, un modificētie sastāvi ar lielāko mullīta saturu pēc apdedzināšanas. Aprēḳinātās siltuma vadāmības koeficienta $\lambda\left(\mathrm{W} \cdot \mathrm{m}^{-1} \cdot \mathrm{K}^{-1}\right)$ vērtības apkopotas III. tabulā.

Materiāliem ar visām izmantotajām piedevām siltuma vadāmības koeficients ir mazāks nekā bāzes sastāva keramikai, kas apdedzināta $1750{ }^{\circ} \mathrm{C}$ temperatūrā. Vismazākā siltuma vadāmība no visiem mērījumos izmantotiem paraugiem ir $1500{ }^{\circ} \mathrm{C}$ temperatūrā apdedzinātam keramikas sastāvam ar $\mathrm{WO}_{3}$ piedevu. Visā temperatūru intervālā tā siltuma vadāmības koeficients šai keramikai ir par apmēram 50 \% mazāks nekā keramikai bez modificējošām piedevām. Minētā sastāva keramikai ar $\mathrm{WO}_{3}$ piedevu ir vislielākā porainība (42\%) un mazs dominējošo poru diametrs (līdz $5 \mu \mathrm{m})$. Samazinātās siltuma vadāmības cēlonis varētu būt arī šì materiāla īpatnējā klasteru tipa struktūra, kur korunda klasteram un mullīta-alumīnija volframāta apkārtējai struktūrai ir atšksirīgas termiskās īpašības. 


\section{Mullītu veidojošu piedevu ietekme uz porainas aluminija oksīda keramikas īpašībām}

Augsti poraina alumīnija oksīda keramika arī iegūta ar koncentrētas suspensijas liešanas metodi, par izejvielām izmantojot $\alpha-\mathrm{Al}_{2} \mathrm{O}_{3}$ $\left(\mathrm{d}_{50}=5,34 \mu \mathrm{m}\right)$ un $\gamma-\mathrm{Al}_{2} \mathrm{O}_{3}\left(\mathrm{~d}_{50}=81,03 \mu \mathrm{m}\right)$ attiecībā 1:3 un 3:1. Suspensijas viskozitātes stabilizēšanai un izžāvēta materiāla mehāniskās izturības palielināšanai pievienots 0,1 \% polielektrolīta karboksi-metilcelulozes nātrija sāls [7]. Poru izmēru sadalījumu $1600{ }^{\circ} \mathrm{C}$ temperatūrā apdedzinātos paraugos galvenokārt ietekmē abu oksīdu daudzumu attiecība. Materiālos, kuru iegūšanai izmantots lielāks daudzums smalkgraudaina $\alpha-\mathrm{Al}_{2} \mathrm{O}_{3}$, ir divi atsevišksi poru izmēru apgabali (9. $a$ att.). Turpretim materiālos, kuru iegūšanai pārsvarā izmantoja $\gamma-\mathrm{Al}_{2} \mathrm{O}_{3}$ ar ievērojami lielāku graudu izmēru, poru izmēru sadalījums ir pilnīgi atškirīgs. To izmēri ir plašā diapazonā no $0,1 \mu \mathrm{m}$ līdz $1000 \mu \mathrm{m}$ (9. $b$ att.). Iegūto materiālu mikrostruktūra un līdz ar to arī īpašības lielā mērā ir atkarīgas no

a

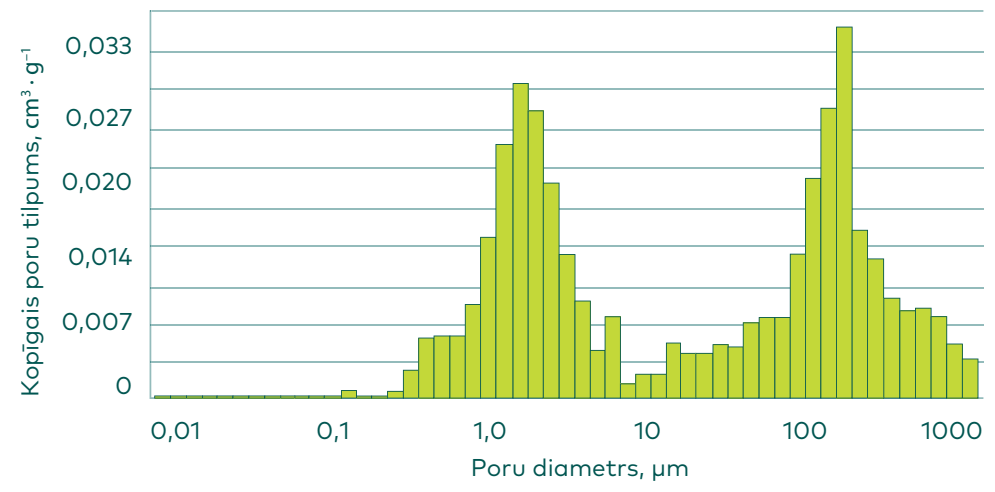

b

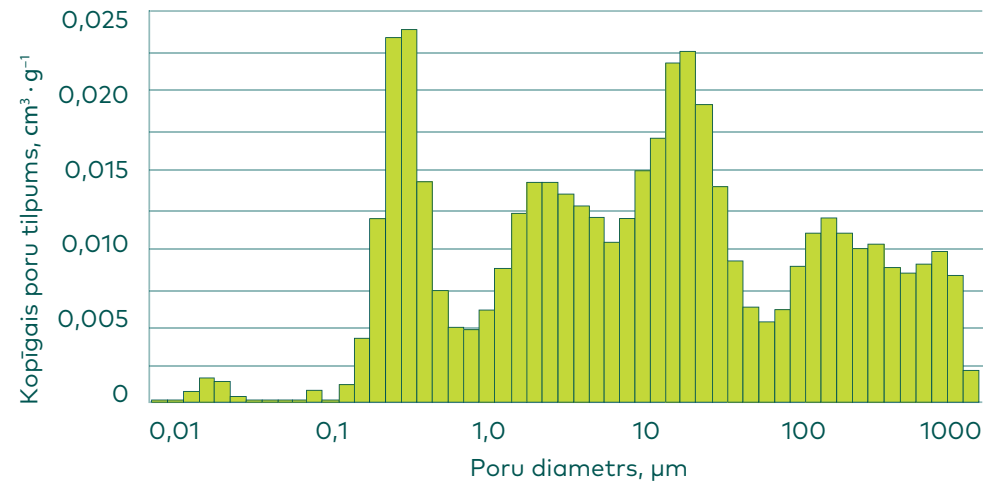

9. att. Poru izmēru sadalījums augsti porainā alumīnija oksīda keramikā atkarībā no $\alpha-\mathrm{Al}_{2} \mathrm{O}_{3}$ un $\gamma-\mathrm{Al}_{2} \mathrm{O}_{3}$ attiecības: $\mathrm{a}-3: 1 ; \mathrm{b}-1: 3$. 
izejvielu graudu izmēriem. Sevišķi ievērojamas ir abu veidu alumīnija oksīda keramikas mehānisko un termisko īpašību atšksirības. Lieces izturība paraugiem ar sastāvā pārsvarā esošiem smalkgraudainiem $\alpha-\mathrm{Al}_{2} \mathrm{O}_{3}$ graudiem ir aptuveni 3 reizes lielāka. Pēc termiskā trieciena izturības pārbaudes šo materiālu lieces pretestība palielinās, salīdzinot ar lieces pretestību pirms termiskā trieciena izturības noteikšanas. Alumīnija oksīda graudu virsmas aktivēšanai un graudu saistības palielināšanai pievienoja $5 \%$ kaolīna.

Noteikta arī malta amorfa $\mathrm{SiO}_{2}$ ietekme uz saisti starp alumīnija oksīda graudiem. Pievienojot sastāvam ar $\alpha-\mathrm{Al}_{2} \mathrm{O}_{3}$ un $\gamma-\mathrm{Al}_{2} \mathrm{O}_{3}$ attiecību 1:2 no $5 \%$ lìdz $10 \%$ maltā $\mathrm{SiO}_{2}$ ar graudu izmēru $\mathrm{d}_{50}=7,0 \mu \mathrm{m}$, izdodas palielināt iegūtās keramikas lieces izturību līdz $12 \mathrm{MPa}$. Saisti starp alumīnija oksīda graudiem rada sekundārais mullīts, kas veidojas uz $\mathrm{Al}_{2} \mathrm{O}_{3}$ graudu virsmas porās. Rezultātā samazinās poru tilpums un apdedzināšanas sarukums, bet tilpuma masa (šķietamais blīvums) praktiski nemainās. Uz alumīnija oksīda virsmas izveidojušos mullīta kristālu vidējais lielums ir $82 \mathrm{~nm}$. Mullīta kristālu molekulārais tilpums $100,79 \mathrm{~cm}^{3} \cdot \mathrm{mol}^{-1}$ ir ievērojami lielāks par mullītu veidojošo oksīdu $\mathrm{SiO}_{2}$ un $\mathrm{Al}_{2} \mathrm{O}_{3}$ molekulāro tilpumu summu, tāpēc arī mullītu saturošas keramikas sarukums samazinās. Optimālais pievienojamā maltā $\mathrm{SiO}_{2}$ daudzums ir $5 \%$, jo tas nodrošina materiāla relatīvi augsto lieces izturību (8 MPa) un pietiekoši augstu vaḷejo porainību (75 \%). Vienlaicīgi $\mathrm{SiO}_{2}$ piedeva samazina sintezētās keramikas lineārās izplešanās temperatūras koeficientu [8].

Ņemot vērā minētos rezultātus, tika pārbaudīta plazmā sintezētu alumīnija oksīda (īpatnējās virsmas laukums $55 \mathrm{~m}^{2} \cdot \mathrm{g}^{-1}$ ) un silīcija karbìda (īpatnējās virsmas laukums $40 \mathrm{~m}^{2} \cdot \mathrm{g}^{-1}$ ) ietekme uz augsti porainas alumīnija oksīda keramikas fizikālajām un mehāniskajām īpašībām. Abu minēto nanopulveru pievienošana materiāla sastāvam notika atšşirīgi. $1650{ }^{\circ} \mathrm{C}$ un $1750{ }^{\circ} \mathrm{C}$ temperatūrās apdedzināta alumīnija oksīda keramiku, kur izejvielām pievienoja $10 \%$ malta amorfa $\mathrm{SiO}_{2}$, piesūcināja ar $1 \%$ un $4 \% \mathrm{Al}_{2} \mathrm{O}_{3}$ nanopulvera suspensiju $48 \mathrm{~h}$. Pēc piesūcināšanas un izžāvēšanas paraugi tika apdedzināti otrreiz $1500{ }^{\circ} \mathrm{C}$ temperatūrā. SiC $\left(2,5 \%, 5 \%\right.$ un $\left.2 \% \mathrm{SiC}+2,5 \% \mathrm{SiO}_{2}\right)$ tika pievienots izejvielu maisijumam, un ar suspensijas liešanu izgatavotos un izžāvētos paraugus tad apdedzināja $1650^{\circ} \mathrm{C}, 1700^{\circ} \mathrm{C}$ un $1750^{\circ} \mathrm{C}$ temperatūrās. Iegūto paraugu tilpuma masa un ūdens uzsūkšanas spēja mainās l̦oti maz, un tā ir attiecīgi no $0,85 \mathrm{~g} \cdot \mathrm{cm}^{-3} \mathrm{li} d z$ 0,90 $\mathrm{g} \cdot \mathrm{cm}^{-3}$ un 66-70\%. Nanopulveru piedevu ietekme uz mehāniskām īpašībām ir atkarīga no pirmās apdedzināšanas temperatūras. Lieces izturība pēc impregnēšanas palielinās tiem paraugiem, kuri sākotnēji bija apdedzināti $1750{ }^{\circ} \mathrm{C}$ temperatūrā. Turpretim elastības modulis, kas noteikts ar nesagraujošo akustisko metodi, palielinās, palielinoties paraugā ievadītajam alumīnija oksīda nanopulvera daudzumam un paaugstinot apdedzināšanas temperatūru [9], [10]. 
a

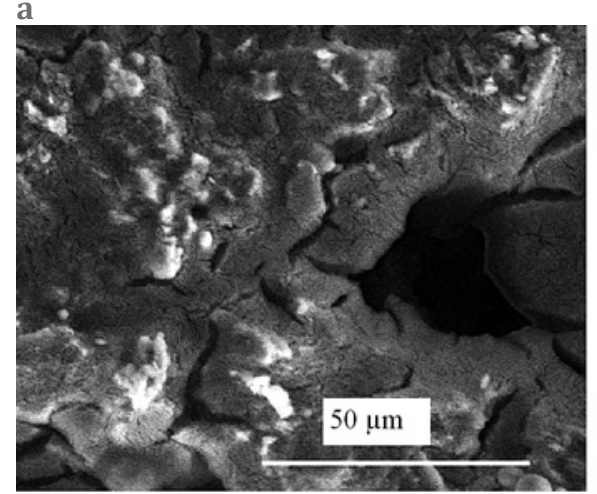

b

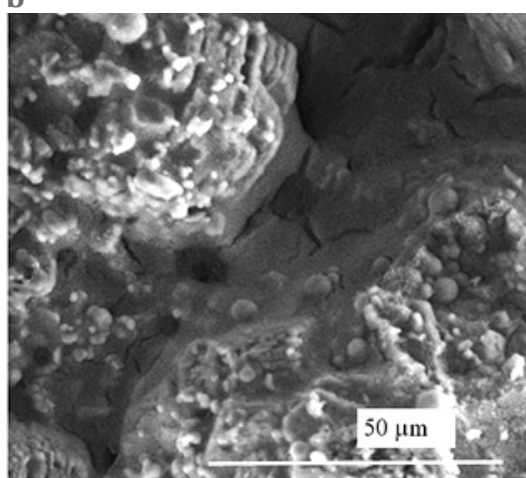

10. att. $\operatorname{Ar} 1 \% \mathrm{Al}_{2} \mathrm{O}_{3}$ suspensiju piesūcinātu $1650{ }^{\circ} \mathrm{C}$ (a) un $1750{ }^{\circ} \mathrm{C}$ (b) temperatūrās apdedzinātu un otrreiz $1600^{\circ} \mathrm{C}$ temperatūrā apdedzinātu paraugu SEM mikrofotogrāfijas (palielinājums 2500 ×).

Plazmā sintezētais alumīnija oksīda nanopulveris nogulsnējas mikrostruktūras tukšumos, un pēc otrās apdedzināšanas tajā veidojas mikroplaisas (10. $a$ att.). Sākotnēji $1750{ }^{\circ} \mathrm{C}$ temperatūrā apdedzināta parauga struktūra pēc piesūcināšanas un otrreizējas termiskās apstrādes ir atšksirīga (10. $b$ att.). Tas arī izskaidro šo paraugu palielināto lieces izturību.

Pievienojot $\mathrm{SiC}$ un $\mathrm{SiO}_{2}$ izejvielu maisījumam, mullīts un korunds veidojas saḳepšanas procesā pēc pasīva SiC oksidācijas mehānisma un sekojošas $\mathrm{SiO}_{2}$ reakcijas ar $\mathrm{Al}_{2} \mathrm{O}_{3}$. Tilpuma masa apdedzinātajiem paraugiem relatīvi nedaudz palielinās, paaugstinot apdedzināšanas temperatūru, bet palielinās sarukums, salīdzinot ar amorfa $\mathrm{SiO}_{2}$ piedevu. SiC nanopulvera piedeva ievērojami palielina augsti porainas alumīnija oksīda keramikas
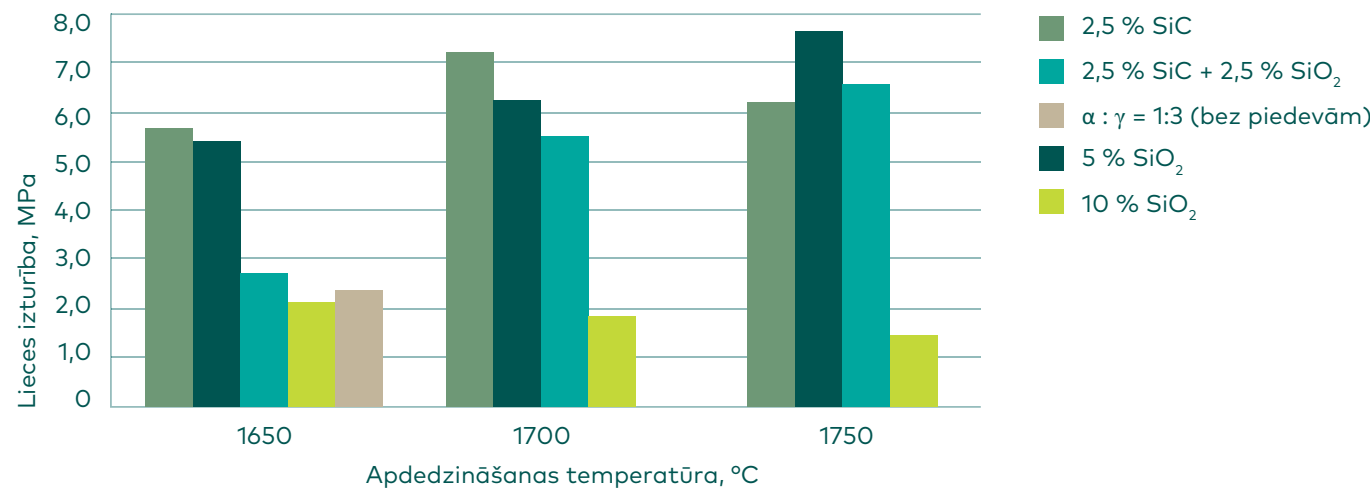

11. att. $\mathrm{SiC}$ un $\mathrm{SiO}_{2}$ piedevu izejvielu maisījumā ietekme uz iegūto paraugu lieces izturību. 


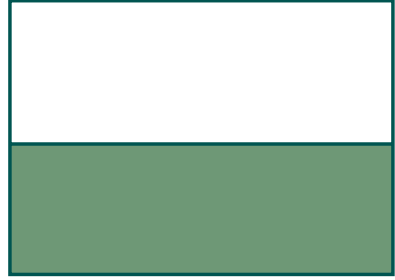

Suspensija veidnē

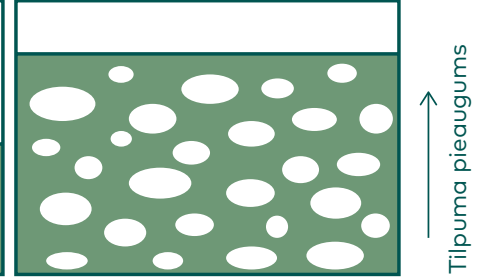

Pēc ūdeṇraža izdalǐšanās

12. att. Augsti porainas keramikas struktūras veidošanās, izmantojot koncentrētas izejvielu suspensijas liešanas metodi.

lieces izturību (11. att.). To var izskaidrot ar ievērojami intensīvāku saķepšanas procesu, ko nosaka $\mathrm{SiC}$ oksidācija materiāla saķ่epināšanas procesa laikā. Vienlaicīgi SiC piedeva palielina arī paraugu termiskā trieciena izturību. Pievienojot izejvielu maisījumam 5 \% SiC, elastības modulis 10 termiskās apstrādes ciklu laikā praktiski nemainās.

Iegūstot augsti porainu oksīdu keramiku ar suspensijas liešanas metodi, bieži poru forma ir elipsveidīga (12. att.). Tas nozīmē, ka materiāla īpašības, seviški spiedes izturība, ir atkarīgas no virziena materiālā, kādā to nosaka. $0,2 \%$ alumīnija pastas pievienošana reakcijas rezultātā palielina sākotnējo suspensijas tilpumu 2 reizes.

Izmantojot iepriekšējos pētījumos iegūtos rezultātus, par piedevām izmantoti dažādi $\mathrm{SiO}_{2}$ avoti, kur aprēksinātais $\mathrm{SiO}_{2}$ saturs būtu 3,7 masas\% un 7,3 masas\%. Dažāda veida $\mathrm{SiO}_{2}$ piedevas ievērojami palielina poru radīto struktūras anizotropiju, salīdzinot ar tīru alumīnija oksīda keramiku. Anizotropija arī palielinās, paaugstinot paraugu apdedzināšanas temperatūru (13. att.). Vēl viens struktūras anizotropijas cēlonis ir atšksirīgais $\alpha$ - un $\gamma-\mathrm{Al}_{2} \mathrm{O}_{3}$ graudu izmērs (attiecīgi $\mathrm{d}_{50}=3 \mu \mathrm{m}$ un $\left.\mathrm{d}_{50}=80 \mu \mathrm{m}\right)$ [11].

Augsti porainas alumīnija oksīda keramikas mehānisko īpašību uzlabošanai ir izmantotas arī citas piedevas, kuras satur vai termiskas apstrādes rezultātā veido $\mathrm{SiO}_{2}$. Par piedevām tika izmantoti: kīimiski tīrs amorfs $\mathrm{SiO}_{2}\left(\mathrm{~d}_{50}=3,7 \mu \mathrm{m}\right)$, mikronu izmēru SiC $\left(\mathrm{d}_{50}=37 \mu \mathrm{m}\right)$, plazmā sintezēts $\mathrm{SiC}\left(\mathrm{d}_{50}=80 \mathrm{~nm}\right)$, plazmā sintezēts $\mathrm{Si}_{3} \mathrm{~N}_{4}\left(\mathrm{~d}_{50}=21 \mathrm{~nm}\right)$, plazmā sintezēts $\mathrm{Si}_{3} \mathrm{~N}_{4}-\mathrm{Al}_{2} \mathrm{O}_{3}-\mathrm{Y}_{2} \mathrm{O}_{3}\left(\mathrm{~d}_{50}=74 \mathrm{~nm}\right)$. Apdedzināšanas rezultātā visos paraugos veidojas mullìts un korunds. Visos paraugos veidojas izstieptas milimetru izmēru poras, kuru garenvirziens ir paralēls veidnes pamatnei. Vislielākā anizotropija ir porām sastāvos ar nanoizmēru pulveru piedevām. Visos gadījumos izmantoti divi piedevu daudzumi: 3,7 ekvivalentie masas $\%$ un 7,3 ekvivalentie masas\% $\mathrm{SiO}_{2}$ [12].

Pievienojot dažādas nanopulveru piedevas, ir iespējams paaugstināt alumīnija oksīda keramikas mehāniskās īpašības. Vienlaicīgi ir 
iespējams saglabāt augstu materiāla škietamo porainību no 56 \% līdz $62 \%$. Pievienojot mikronu izmēru piedevas, šksietamā porainība saglabājas nedaudz augstāka no 58 \% līdz 64 \%, bet mehāniskā izturība nepalielinās vai pat nedaudz samazinās. Šādus rezultātus var pamatot ar to, ka suspensijas ar nanopulveru piedevu ir homogēnākas un palielinās kontaktvirsmas laukums starp komponentēm saķepšanas procesā. Vislielākā lieces izturība ir paraugiem ar 3,7\% $\mathrm{Si}_{3} \mathrm{~N}_{4}-\mathrm{Al}_{2} \mathrm{O}_{3}-\mathrm{Y}_{2} \mathrm{O}_{3}$ piedevu, kas apdedzināti $1750{ }^{\circ} \mathrm{C}$ temperatūrā. Lieces izturība šiem paraugiem palielinājusies no 3,2 MPa (nemodificētiem paraugiem) līdz 11,0 MPa, bet šķietamā porainība attiecīgi samazinājusies no 61 \% līdz 58 \%. Gan lieces izturība, gan tilpuma masa paraugiem, kas apdedzināti gan $1650{ }^{\circ} \mathrm{C}$, gan $1750{ }^{\circ} \mathrm{C}$ temperatūrās samazinās, palielinoties $\mathrm{SiO}_{2}$ saturam no 3,7 ekvivalentajiem masas\% līdz 7,3 ekvivalentajiem masas\%.
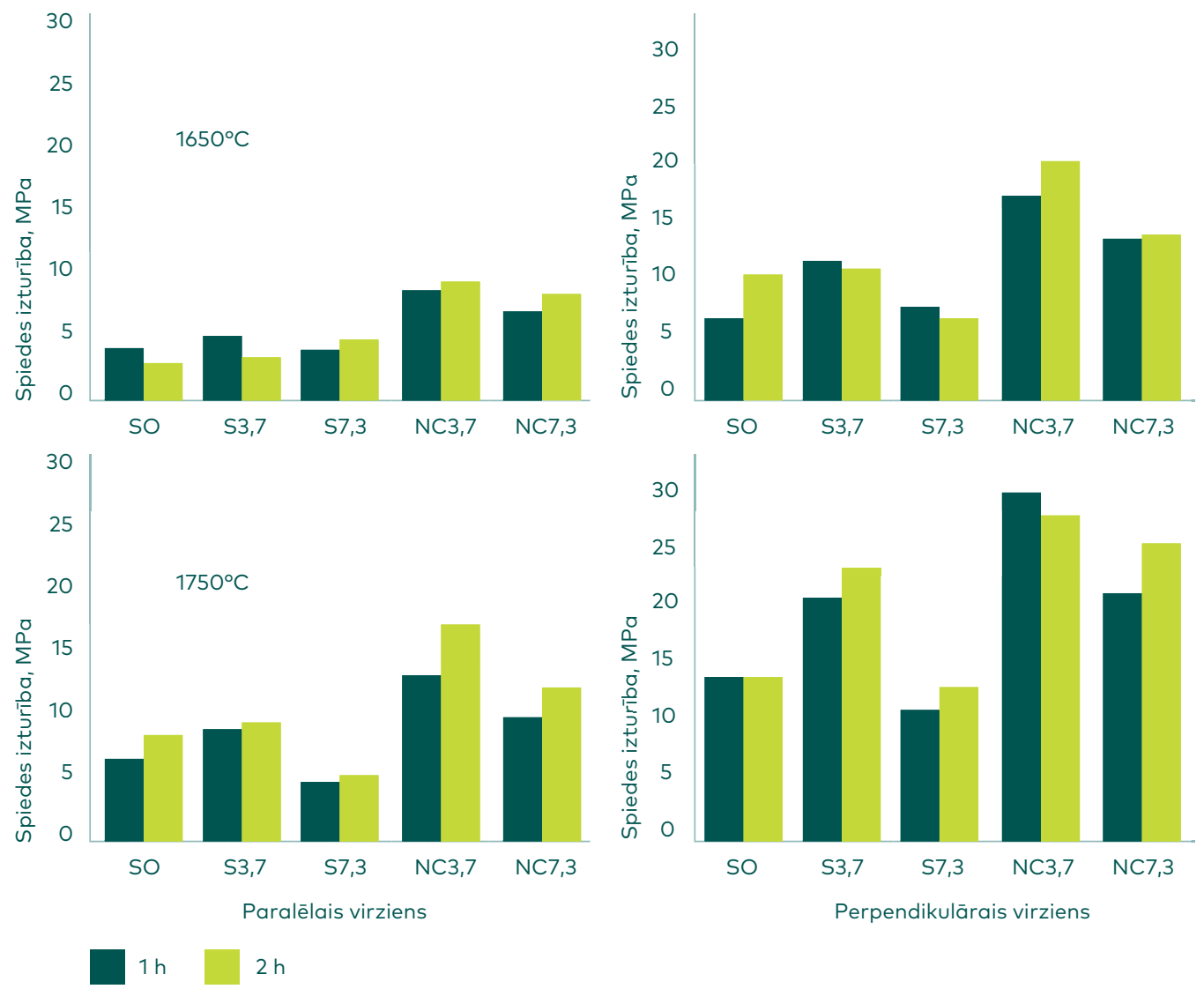

13. att. Spiedes stiprības atkarība no sastāva, apdedzināšanas temperatūras, izturēšanas laika un slogošanas virziena (sastāvu apzīmējumi IV. tabulā). 
$2018 / 35$

a

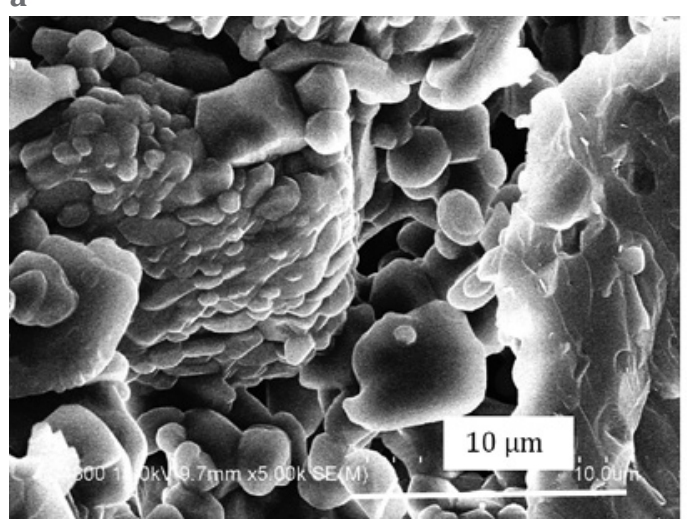

b

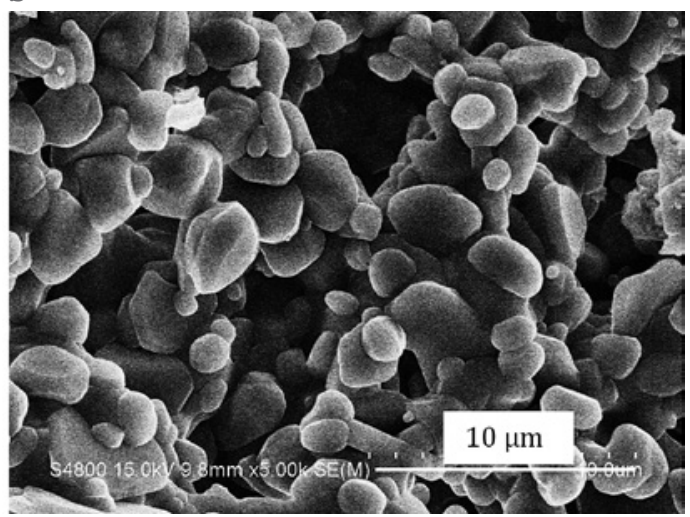

14. att. SEM mikrofotogrāfijas porainai alumīnija oksīda keramikai $\operatorname{ar} \mathrm{SiO}_{2}$ piedevu, kas apdedzināta $1750{ }^{\circ} \mathrm{C}$ temperatūrā: a - 3,7 \% $\mathrm{SiO}_{2} ; \mathrm{b}-7,3 \% \mathrm{SiO}_{2}$.

Tas norāda, ka materiāla īpašības vairāk ietekmē sīkgraudaina mullīta veidošanās uz alumīnija oksīda graudu virsmas nekā materiāla sablīvēšanās, palielinoties $\mathrm{SiO}_{2}$ daudzumam. Palielinoties mikronu izmēra $\mathrm{SiO}_{2}$ pulvera saturam, palielinās sistēmas heterogenitāte, un veidojas vājāks kontakts starp $\mathrm{Al}_{2} \mathrm{O}_{3}$ graudiem, kas arī ietekmē materiāla mehāniskās īpašỉbas. Šksietamās porainības samazināšanos un tilpuma masas palielināšanos straujāk ietekmē apdedzināšanas temperatūras palielināšanās, kā modificējošas piedevas izmantojot dažādus nanoizmēru pulverus. SEM attēlos (14. $a$ att.) ir redzams grauds, kurš pat pēc pārejas uz $\alpha-\mathrm{Al}_{2} \mathrm{O}_{3}$ modifikāciju ir saglabājis savas kontūras un kuru aptver $\alpha-\mathrm{Al}_{2} \mathrm{O}_{3}$ graudi

IV. tabula

Sintezēto materiālu raksturojumi

\begin{tabular}{|c|c|c|c|c|c|c|}
\hline Sastāvi & Apzīmējums & $\begin{array}{l}\text { Tilpuma } \\
\text { masa, } \\
\mathrm{g} \cdot \mathrm{cm}^{-3}\end{array}$ & $\begin{array}{c}\text { Šḳietamā } \\
\text { porainība, } \\
\%\end{array}$ & $\begin{array}{l}\text { Lieces } \\
\text { izturība, } \\
\mathrm{MPa}\end{array}$ & $\begin{array}{c}\text { Termiskā } \\
\text { izplešanās } \alpha, \\
10^{6} \cdot{ }^{\circ} \mathrm{C}^{-1} \\
\left(1000^{\circ} \mathrm{C}\right)\end{array}$ & $\begin{array}{c}\lambda 30^{\circ} \mathrm{C} \\
\left(\text { un } 1000^{\circ} \mathrm{C} \text { ), }\right. \\
\mathrm{W} \cdot \mathrm{m}^{-1} \cdot \mathrm{K}^{-1}\end{array}$ \\
\hline $\begin{array}{l}\mathrm{Bez} \mathrm{SiO}_{2} \\
\text { piedevas }\end{array}$ & So & 1,09 & 61,0 & 3,2 & 9,4 & $2,99(1,13)$ \\
\hline $3,7 \% \mathrm{SiO}_{2}$ & $\mathrm{~S} 3,7$ & 1,14 & 58,0 & 4,2 & 9,7 & $2,24(1,33)$ \\
\hline $7,3 \% \mathrm{SiO}_{2}$ & $\mathrm{~S} 7,3$ & 1,01 & 62,1 & 2,1 & 9,4 & $1,23(1,12)$ \\
\hline $\begin{array}{c}3,7 \% \mathrm{SiC} \\
\text { plazmā sintezēts }\end{array}$ & $\mathrm{NC} 3,7$ & 1,26 & 57,5 & 9,3 & 9,2 & $3,07(1,23)$ \\
\hline $\begin{array}{c}7,3 \% \mathrm{SiC} \\
\text { plazmā sintezēts }\end{array}$ & $\mathrm{NC7}, 3$ & 1,20 & 58,2 & 4,7 & 8,4 & $1,90(1,05)$ \\
\hline
\end{tabular}


ar ievērojami mazāku izmēru. Starp alumīnija oksīda graudiem pastāv relatīvi lielas mikronu izmēru poras, kas radušās alumīnija pulvera reakcijā ar ūdeni suspensijas sabiezēšanas procesā (14. $b$ att.).

Iepriekšējie rezultāti parādīja, ka labākās īpašības uzrāda paraugi, kas apdedzināti $1750{ }^{\circ} \mathrm{C}$ temperatūrā. Tādēl porainās alumīnija oksīda keramikas termisko īpašību analīzei izmantoti $1750{ }^{\circ} \mathrm{C}$ temperatūrā apdedzināti paraugi ar 3,7 \% un 7,3 \% amorfa $\mathrm{SiO}_{2}$ un plazmā sintezēta SiC piedevām [13]. Šo paraugu īpašības apkopotas IV. tabulā.

Palielinot $\mathrm{SiO}_{2}$ saturu no 3,7 \% līdz 7,3 \%, sintezēto paraugu šksietamā porainība palielinās, un rezultātā samazinās paraugu tilpuma masa, lieces izturība, lineārās izplešanās temperatūras koeficients un siltuma vadāmības koeficients. Nosakot termiskā trieciena izturību ar nesagraujošu akustisku metodi, kas mēra skaṇas izplatīšanās frekvenci materiālā, elastības modulis vismazāk mainās paraugiem, kuros pievienots 7,3 \% plazmā sintezētā SiC. Tas norāda uz mazāku plaisu daudzumu struktūrā, kas ir radušās termisku spriegumu rezultātā strauju temperatūras svārstību laikā. Domājams, ka poraina mikrostruktūra aizkavē plaisu izplatīšanos. SEM mikrofotogrāfijās redzamas plaisas pašos graudos. Pētītās augsti porainās alumīnija oksīda keramikas termiskā trieciena izturības rezultāti liecina, ka to vairāk ietekmē materiāla mikrostruktūra nekā mullīta klātbūtne.

Šo pašu sastāvu porainajiem keramikas materiāliem papildus noteikta siltuma vadāmība $30-1100{ }^{\circ} \mathrm{C}$ temperatūrā ar lāzera impulsa analīzes metodi Erlangenas-Nirnbergas universitātē (LFA 457, Netzsch instruments, Vācija). Materiālu poru struktūra, t. i., poru izmērs un poru sieniṇu biezums, tika analizēta ar rentgenstaru mikrodatortomogrāfijas ( $\mu \mathrm{DT}$ ) palīdzību Erlangenas-Nirnbergas universitātē. Materiālu poru struktūras analīzei izmantota arī dzīvsudraba porozimetrija (PoreMaster, Quantachrome Instrument, ASV) un slāpekḷa adsorbcijas (BET) metodes (Nova1200e, Quantachrome Instrument, ASV).

Zemākā siltuma vadāmība ir paraugiem, kuros izejvielu maisījumam pievienots $7,3 \%$ amorfa $\mathrm{SiO}_{2}$. Vairumā gadījumu palielinot vienas un tās

V. tabula

Siltuma vadāmība pētītajiem paraugiem

\begin{tabular}{ccccc}
\hline \multirow{2}{*}{ Sastāvs } & \multicolumn{2}{c}{$1650^{\circ} \mathrm{C}$ apdedzināti paraugi } & \multicolumn{2}{c}{$1750^{\circ} \mathrm{C}$ apdedzināti paraugi } \\
\cline { 2 - 5 } & $\lambda_{30}, \mathrm{~W} \cdot \mathrm{m}^{-1} \cdot \mathrm{K}^{-1}$ & $\lambda_{1100}, \mathrm{~W} \cdot \mathrm{m}^{-1} \cdot \mathrm{K}^{-1}$ & $\lambda_{30}, \mathrm{~W} \cdot \mathrm{m}^{-1} \cdot \mathrm{K}^{-1}$ & $\lambda_{1100}, \mathrm{~W} \cdot \mathrm{m}^{-1} \cdot \mathrm{K}^{-1}$ \\
\hline $\mathrm{SO}$ & 1,84 & 0,88 & 2,99 & 1,25 \\
$\mathrm{~S} 3,7$ & 1,54 & 0,81 & 2,23 & 1,39 \\
$\mathrm{~S} 7,3$ & 0,77 & 0,80 & 1,23 & 1,23 \\
$\mathrm{NC} 3,7$ & 2,23 & 1,03 & 3,07 & 1,34 \\
$\mathrm{NC} 7,3$ & 1,40 & 0,83 & 1,90 & 1,12 \\
\hline
\end{tabular}


pašas piedevas daudzumu no 3,7 \% līdz 7,3 \%, siltuma vadāmība gan istabas temperatūrā, gan $1100{ }^{\circ} \mathrm{C}$ temperatūrā samazinās. Siltuma vadāmību ietekmē arī paraugu apdedzināšanas temperatūra - paaugstinot paraugu apdedzināšanas temperatūru, siltuma vadāmības koeficients palielinās (V. tabula) [14].

Dzīvsudraba porozimetrijas rezultāti liecina, ka visos ar koncentrētas izejvielu suspensijas liešanas paṇēmienu iegūtajos materiālos ir trīs poru tilpuma sadalījuma apgabali. Poras, kuru izmērs ir lielāks par $100 \mu \mathrm{m}$, veidojas suspensijā, un tās sabiezēšanas laikā ūdennraža izdalīšanās rezultātā poru izmērus un formu nosaka galvenokārt suspensijas viskozitāte un izejvielu pulveru dạ̣iņu izmēri. Otrs raksturīgs poru izmēru apgabals ir 2-20 $\mu \mathrm{m}$. Mikronu izmēru $\mathrm{SiO}_{2}$ pulvera piedeva palielina šo izmēru poru tilpumu, bet nanoizmēru SiC savukārt samazina šī diapazona poru tilpumu. Ievērojamākās izmaiṇas atkarībā no piedevu rakstura un apdedzināšanas temperatūras ir to poru izmēru diapazonā, kuras mazākas par $2 \mu \mathrm{m}$. Paaugstinot apdedzināšanas temperatūru no $1650^{\circ} \mathrm{C}$ uz $1750^{\circ} \mathrm{C}$, ši izmēra poru tilpuma maksimums pārbīdās lielākā poru diametra virzienā, bet poru īpatnējās virsmas laukums samazinās. Tas liecina par poru sieniṇu saķepšanas intensifikāciju mazo poru izmēru samazināšanās rezultātā. $1750{ }^{\circ} \mathrm{C}$ temperatūrā apdedzinātos paraugos saķepšanu visvairāk intensificē $\mathrm{SiO}_{2}$ piedeva. Vislielākā valẹjāā porainība pēc dzīvsudraba porozimetrijas rezultātiem ir $1650^{\circ} \mathrm{C}$ temperatūrā apdedzinātiem paraugiem ar 7,3 \% $\mathrm{SiO}_{2}$ piedevu, bet vismazākā no šajā temperatūrā apdedzinātiem paraugiem ar 7,3 \% SiC piedevu. $1750{ }^{\circ} \mathrm{C}$ temperatūrā apdedzinātos paraugos valẹjēā porainība ir atkarīga no pievienotā $\mathrm{SiO}_{2}$ daudzuma - palielinot $\mathrm{SiO}_{2}$ daudzumu, vaḷējā porainība palielinās.

Mikrostruktūras raksturošanai izmantotā rentgenstaru mikrotomogrāfija ḷauj aprēķināt poru un poru starpsienu izmēru izmainu atkarībā no piedevām un apdedzināšanas temperatūras (VI. tabula). Apdedzināšanas temperatūras maiṇa un piedevas maz ietekmē vidējo poru sieniṇu

VI. tabula

Vidējie poru un poru sieniṇu izmēri

\begin{tabular}{|c|c|c|c|c|}
\hline \multirow[t]{2}{*}{ Sastāvs } & \multicolumn{2}{|c|}{$1650^{\circ} \mathrm{C}$ apdedzināti paraugi } & \multicolumn{2}{|c|}{$1750^{\circ} \mathrm{C}$ apdedzināti paraugi } \\
\hline & $\begin{array}{l}\text { Vidējais poru } \\
\text { izmērs, } \mu \mathrm{m}\end{array}$ & $\begin{array}{l}\text { Vidējais sieninu } \\
\text { biezums, } \mu \mathrm{m}\end{array}$ & $\begin{array}{l}\text { Vidējais poru } \\
\text { izmērs, } \mu \mathrm{m}\end{array}$ & $\begin{array}{l}\text { Vidējais sieniṇu } \\
\text { biezums, } \mu \mathrm{m}\end{array}$ \\
\hline so & 211 & 40 & 111 & 35 \\
\hline $\mathrm{NC} 3,7$ & 188 & 39 & 154 & 39 \\
\hline $\mathrm{S} 3,7$ & 192 & 47 & 198 & 47 \\
\hline $\mathrm{s} 7,3$ & 175 & 47 & 217 & 45 \\
\hline
\end{tabular}


a

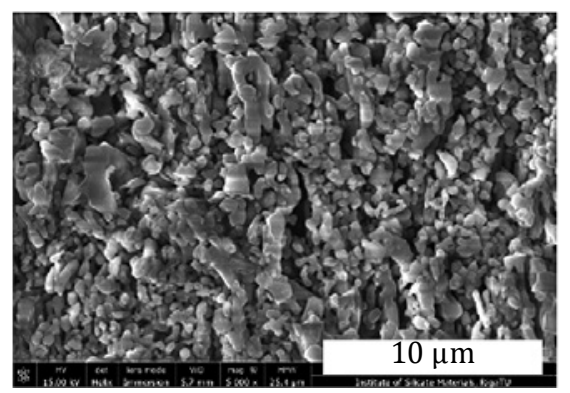

b

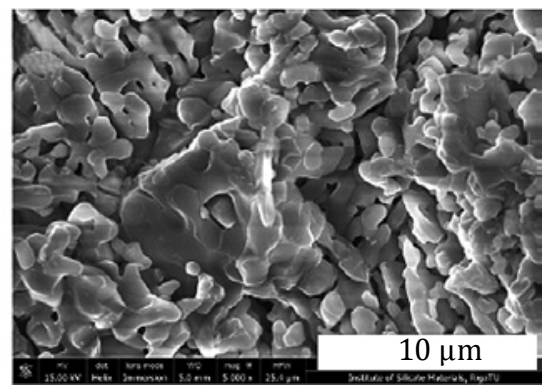

15. att. Paraugu NC7,3-1650 (a) un NC7,3-1750 (b) mikrostruktūra.

biezumu, bet diezgan ievērojami izmaina vidējo poru izmēru. Salīdzinot $1650{ }^{\circ} \mathrm{C}$ temperatūrā apdedzinātos paraugus, piedevas samazina vidējo poru izmēru, bet $1750{ }^{\circ} \mathrm{C}$ temperatūrā apdedzinātos paraugos ietekme ir pretēja. Šie rezultāti atbilst klasiskajai keramikas saķepšanas procesa teorijai, kad šķidrās fāzes klātbūtnē materiālā lielākās poras "aug” uz mazāko poru rēkina, t. i., mazākās poras apvienojas vai pievienojas lielākajām porām.

Šo secinājumu apstiprina arī skenējošās elektronu mikroskopijas (augstas izškirtspējas lauka emisijas zema vakuuma elektronu mikroskops FEI Nova NanoSEM 650, FEI Company, Nīderlande) rezultāti. Pēc šiem rezultātiem izejvielu sākotnējais sastāvs ievērojami ietekmē materiālu struktūru. Piedevas, it seviški SiC nanopulveris, l̦auj iegūt paraugus ar kompaktāku struktūru pēc apdedzināšanas $1750{ }^{\circ} \mathrm{C}$ temperatūrā. Paraugos ar SiC piedevu, paaugstinot apdedzināšanas temperatūru, novērota kristālu augšana (15. att.), kam par cēloni ir škidrās fāzes klātbūtne.

\section{Augsti poraina kordierīta keramika}

Kordierīts $2 \mathrm{MgO} \cdot 2 \mathrm{Al}_{2} \mathrm{O}_{3} \cdot 5 \mathrm{SiO}_{2}$ ir viens no kristāliskiem savienojumiem ar mazu lineārās izplešanās temperatūras koeficientu $3 \cdot 10^{-6}-6 \cdot 10^{-6} \mathrm{~K}^{-1}$. Kordierīta keramikas sintēzei var tikt izmantotas dažādas magnija oksīdu saturošas izejvielas. Mūsu darbā izmantots talks kopā ar kaolīnu un $\gamma-\mathrm{Al}_{2} \mathrm{O}_{3}$. Tāpat kā iepriekšējās nodaḷās par alumīnija oksīda, mullīta, $\mathrm{TiO}_{2}$ un $\mathrm{ZrO}_{2}$ saturošu keramiku, sintēzes metode saistīta ar ūden,raža izdalīšanos alumīnija pulvera reakcijā ar ūdeni koncentrētā izejvielu suspensijā. İpašību modificēšanai izmantots malts amorfs $\mathrm{SiO}_{2}$ ar dal̦inu izmēru 1,5 $\mu \mathrm{m}$, nestabilizēts $\mathrm{ZrO}_{2}$ un plazmā sintezēts nanoizmēra SiC. Paraugi apdedzināti $1250-1450{ }^{\circ} \mathrm{C}$ temperatūrās. Rentgena staru 
fāžu analīze uzrāda trīs kristāliskās pamatfāzes: kordierītu, mullītu un korundu, kuras pastāv visā apdedzināšanas temperatūru intervālā. Sastāvos bez piedevām papildus visās apdedzināšanas temperatūrās pastāv arī špinelis. Kordierīta un mullīta kristālisko fāžu līniju intensitāte palielinās, paaugstinot paraugu apdedzināšanas temperatūru. Amorfā $\mathrm{SiO}_{2}$ piedevas gadỉjumā temperatūrās virs $1300^{\circ} \mathrm{C}$ parādās kristobalīts. Savukārt paraugos, kur izejvielu maisījumam pievienots $\mathrm{ZrO}_{2}$, temperatūrās virs $1250{ }^{\circ} \mathrm{C}$ veidojas $\mathrm{ZrSiO}_{4}$ [15].

Par materiāla poru struktūru un tās atšksirībām liecina dzīvsudraba porozimetrija. 16. att. salīdzinātas poru izmēru histogrammas paraugam bez piedevām un paraugam ar kopīgu $\mathrm{SiO}_{2}$ un $\mathrm{ZrO}_{2}$ piedevu. Atšksirības nav uzskatāmas. Labāku priekšstatu dod logaritmiskais diferenciālais poru tilpuma sadalījums atkarībā no poru diametra (17. att.). $\mathrm{SiO}_{2}$ un $\mathrm{SiO}_{2}$ un SiC kopīga piedeva pārbīda lielākā tilpuma poras uz lielākiem izmēriem, un vienlaicīgi šo poru tilpums samazinās. Savukārt vienlaicīga

a

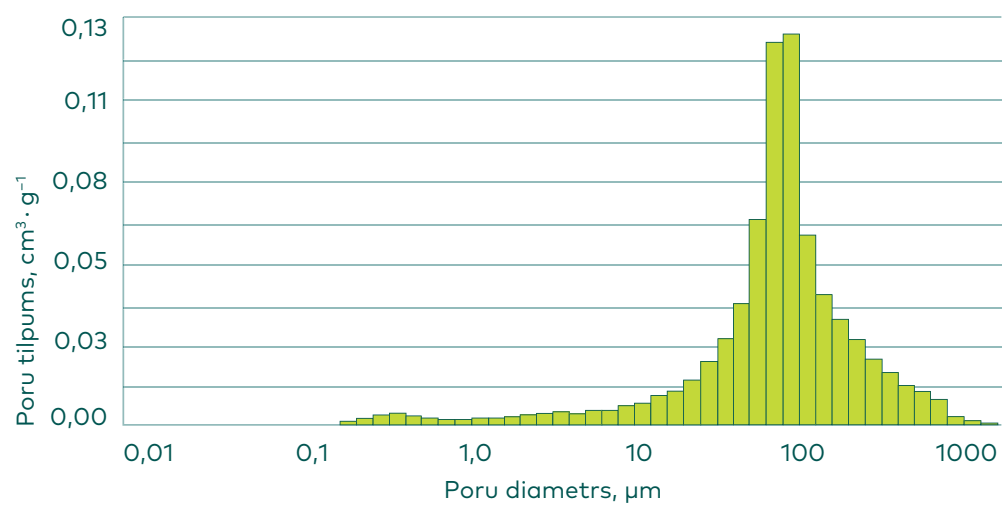

b

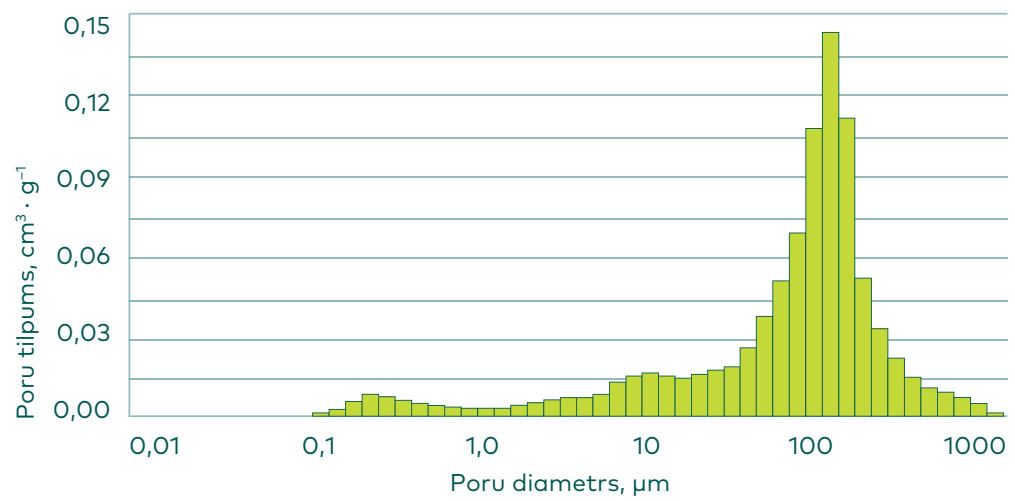

16. att. $1350{ }^{\circ} \mathrm{C}$ temperatūrā apdedzinātas kordierīta keramikas poru izmēru histogrammas: a - bez piedevām; b - ar $\mathrm{SiO}_{2}$ un $\mathrm{ZrO}_{2}$ piedevu. 


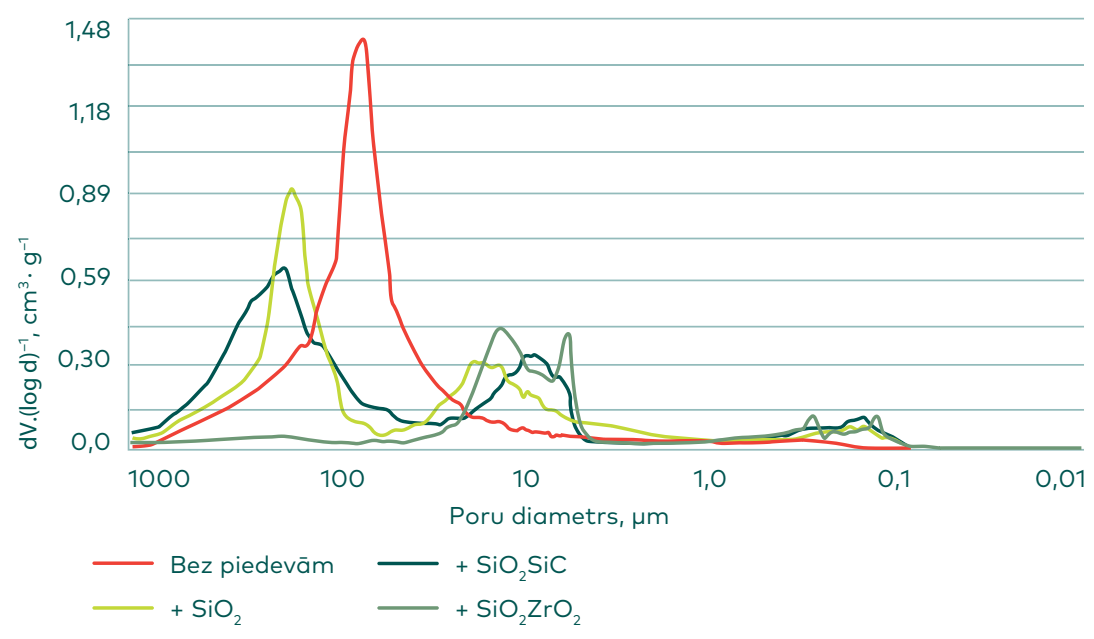

17. att. Logaritmiskais diferenciālais poru tilpums atkarībā no poru diametra kordierīta paraugiem bez un ar piedevām. Apdedzināšanas temperatūra $1350{ }^{\circ} \mathrm{C}$.

$\mathrm{SiO}_{2}$ un $\mathrm{ZrO}_{2}$ piedeva būtiski izmaina poru izmēru sadalījumu. Šajā materiālā lielākais tilpums ir porām ar diametru 4-10 $\mu \mathrm{m}$. Šāda sarežǵìta poru struktūra ietekmē arī sintezētās keramikas īpašības, piemēram, mehānisko izturību, lineāro termisko izplešanos un siltuma vadāmību. Paraugu bez piedevām spiedes izturība, paaugstinot apdedzināšanas temperatūru virs $1300{ }^{\circ} \mathrm{C}$, samazinās. Piedevu ietekmi uz paraugu spiedes izturību lietderīgāk analizēt vienā un tajā pašā temperatūrā iegūtiem paraugiem. Vislielākā spiedes izturība ir paraugiem ar mazāko diferenciālo poru tilpumu, t. i., paraugiem, kuri iegūti no izejvielu maisījuma ar $\mathrm{SiO}_{2}$ un $\mathrm{ZrO}_{2}$ piedevu (VII. tabula). Pozitīvā $\mathrm{SiO}_{2}$ ietekme saistīta ar sīku mullīta kristālu papildus veidošanos uz alumīnija oksīda graudu virsmas, kuri samazina starp graudiem esošo poru tilpumu, ko uzskatāmi apstiprina poru tilpuma sadalījuma līkne 17. att.

VII. tabula

Sintezēto paraugu spiedes izturība

\begin{tabular}{|c|c|c|c|}
\hline $\begin{array}{l}\text { Saḳepināšanas } \\
\text { temperatūra, }{ }^{\circ} \mathrm{C}\end{array}$ & $\begin{array}{c}\text { Paraugi bez } \\
\text { piedevām, MPa }\end{array}$ & $\begin{array}{l}\text { Paraugi ar } \mathrm{SiO}_{2} \\
\text { piedevu, } \mathrm{MPa}\end{array}$ & $\begin{array}{c}\text { Paraugi ar } \mathrm{SiO}_{2} \text { un } \\
\mathrm{ZrO}_{2} \text { piedevām, } \mathrm{MPa}\end{array}$ \\
\hline 1250 & - & - & 2,99 \\
\hline 1300 & 2,96 & 2,40 & 1,47 \\
\hline 1350 & 1,70 & 2,51 & 3,48 \\
\hline 1400 & $<1$ & 1,62 & $<1$ \\
\hline
\end{tabular}


Praktiskā ziṇā svarīga kordierīta keramikas īpašība ir termiskā izplešanās. Ir konstatēts, ka lineārās izplešanās temperatūras koeficientu ietekmē ne tikai parauga sastāvs un izmantotās izejvielas, bet arī viena un tā paša sastāva saḳepināšanas temperatūra. $\mathrm{ZrO}_{2}$ piedeva ievērojami palielina lineārās izplešanās temperatūras koeficientu. Piemēram, $1250{ }^{\circ} \mathrm{C}$ temperatūrā sak̦epinātiem paraugiem bez $\mathrm{ZrO}_{2}$ piedevas $\alpha_{200-1000}=4,45 \cdot 10^{-6} \mathrm{~K}^{-1}$, bet ar $\mathrm{ZrO}_{2}$ piedevu $\alpha_{200-1000}=7,66 \cdot 10^{-6} \mathrm{~K}^{-1}$. Salīdzinot izplešanās koeficientus paraugiem ar $\mathrm{SiO}_{2}$ piedevu, redzams, ka saķepināšanas temperatūras paaugstināšana samazina parauga lineārās izplešanās temperatūras koeficientu no $6,22 \cdot 10^{-6} \mathrm{~K}^{-1} \mathrm{lī} \mathrm{dz} 4,87 \cdot 10^{-6} \mathrm{~K}^{-1}$.

Siltuma vadāmības mērījumi temperatūru intervālā no istabas temperatūras līdz $1100{ }^{\circ} \mathrm{C}$ parāda, ka siltuma vadāmības koeficients augsti porainai keramikai (porainība $>50 \%$ ) līdz $600{ }^{\circ} \mathrm{C}$ temperatūrai ir maz atkarīgs no porainības izmain,ām, un tas ir $0,2-0,3 \mathrm{~W} \cdot \mathrm{m}^{-1} \cdot \mathrm{K}^{-1}$ robežās, bet augstākās temperatūrās tas strauji palielinās, un paraugos bez piedevām vai ar $\mathrm{SiO}_{2}$ piedevu tas sasniedz $0,8-0,9 \mathrm{~W} \cdot \mathrm{m}^{-1} \cdot \mathrm{K}^{-1} \cdot \mathrm{ZrO}_{2}$ piedeva bāzes sastāvam palielina $\lambda$ zemākajās temperatūrās līdz $0,35-0,40 \mathrm{~W} \cdot \mathrm{m}^{-1} \cdot \mathrm{K}^{-1}$.

Izmantojot koncentrētas suspensijas liešanas paṇēmienu augsti porainas keramikas iegūšanai, san,emts arī Latvijas patents [16].

\section{Pateicības}

Pētījumi par augsti porainu oksīdu keramiku un tās izmantošanu veikti ar Latvijas Izglītības Ministrijas finansēto Valsts pētījumu programmas Nr.2014.10-4/VPP-6/4 "Meža un zemes dzīḷ resursu izpēte, ilgtspējīga izmantošana - jauni produkti un tehnologijas (ResProd)", 6. apakšprojekts "Zemes dzīḷu resursu izpēte dabisko izejvielu dažādošanai un jaunu tehnologiju izstrādei (GEO)” finansiālu atbalstu. Sevišksa pateicība Fridriha-Aleksandra Erlangenas-Nirnbergas universitātes Tehniskās fakultātes Stikla un keramikas katedrai par iespēju izmantot viṇu iekārtas materiālu uzbūves un īpašību pētīšanai, kā arī Bavārijas Izglīīibas un zinātnes ministrijai un tehniskās keramikas firmai Rauschert par finansiālu atbalstu.

\section{LITERATŪRAS SARAKSTS}

[1] G. Buḷa, R. Švinka, and V. Švinka, "Refractory foam ceramics from zirconia, alumina and kaolin - preparation and properties," In Proc. of $10^{\text {th }}$ Int. Conf. of Eur. Ceram. Soc., 2007, pp. 1942-1945.

[2] R. Svinka, V. Svinka, and A. Butlers, "Light weight refractory materials on kaoline and alumina basis," In Proc. of V Intern. Conf. Refractories, Furnaces and thermal insulations, 2008, pp. 41-47.

[3] T. Juettner, H. Moertel, V. Svinka, and R. Svinka, "Structure of kaoline-alumina based foam ceramics for high temperature application," Journal of 
European Ceramic Society, vol. 27, no. 2, pp. 1435-1441, Dec. 2007. https:// doi.org/10.1016/j.jeurceramsoc.2006.04.029

[4] L. Mahnicka, R. Svinka, and V. Svinka, "Influence of kaolin and firing temperature on the mullite formation in porous mullite-corundum materials," IOP Conference Series: Materials Science and Engineering, vol. 25, p. 012008, Dec. 2011. https://doi.org/10.1088/1757-899x/25/1/012008

[5] L. Mahnicka, R. Svinka, and V. Svinka, "Properties of porous mullite ceramics doped with $\mathrm{MgO}$ and produced by slip casting method," In Proc. of VII International Scientific Conference "Refractories, Furnaces and Thermal Insulations 2012", 2012, pp. 130-135.

[6] L. Mahnicka-Goremikina, R. Svinka, and V. Svinka, "Influence of Metal Oxides Additives on the Porous Mullite Ceramics," Key Engineering Materials, vol. 604, pp. 293-296, Mar. 2014. https://doi.org/10.4028/www. scientific.net/kem.604.293

[7] R. Svinka, V. Svinka, I. Zake, and A. Butlers, "Influence of some additives on the properties of porous alumina ceramic," Chemine Technologija, vol. 50, no. 1, pp. 51-55.

[8] R. Svinka, V. Svinka, and I. Zake, "Silica containing highly porous alumina ceramic," IOP Conference Series: Materials Science and Engineering, vol. 18, no. 18, p. 182008, Apr. 2011. https://doi. org/10.1088/1757-899x/18/18/182008

[9] I. Zake, R. Svinka, V. Svinka, and E. Palcevskis, "Alumina lightweight ceramics modified with plasma synthesized nanopowders," IOP Conference Series: Materials Science and Engineering, vol. 25, p. 012021, Dec. 2011. https://doi.org/10.1088/1757-899x/25/1/012021

[10] I. Zake, R. Svinka, and V. Svinka, "Effect of Various Mullite Precursors on Properties of Porous Alumina-Mullite Ceramics" In Proc. of the International Scientific Conference "Refractories, Furnaces and Thermal Insulations", 2012, pp. 124-129.

[11] I. Zake-Tiluga, R. Svinka, and V. Svinka, "Anisotropy of Compressive Strength in Porous Alumina Ceramics," Key Engineering Materials, vol. 604, pp. 153-156, Mar. 2014. https://doi.org/10.4028/www.scientific. net/kem.604.153

[12] I. Zake-Tiluga, R. Svinka, and V. Svinka, "Highly porous corundummullite ceramics - Structure and properties," Ceramics International, vol. 40, no. 2, pp. 3071-3077, Mar. 2014. https://doi.org/10.1016/j. ceramint.2013.09.139

[13] I. Zake-Tiluga, V. Svinka, R. Svinka, and L. Grase, "Thermal shock resistance of porous $\mathrm{Al}_{2} \mathrm{O}_{3}$-mullite ceramics," Ceramics International, vol. 41, no. 9, pp. 11504-11509, Nov. 2015. https://doi.org/10.1016/j. ceramint.2015.05.116

[14] I. Zake-Tiluga, V. Svinka, R. Svinka, B. Zierath, P. Greil, and T. Fey, "Thermal conductivity and microstructure characterisation of lightweight alumina and alumina-mullite ceramics," Journal of the European Ceramic Society, vol. 36, no. 6, pp. 1469-1477, May 2016. https://doi.org/10.1016/j. jeurceramsoc.2015.12.026 
[15] R. Svinka, V. Svinka, and J. Bobrovik, "Modification of Porous Cordierite Ceramic," Key Engineering Materials, vol. 721, pp. 322-326, Dec. 2016. https://doi.org/10.4028/www.scientific.net/kem.721.322

[16] V. Švinka, R. Švinka, A. Butlers, and I. Zakse, "Keramisks filtrs," LV Patent LV14078, 20 May, 2010.

Visvaldis Švinka, Dr. habil. sc. ing., asociētais profesors un Rīgas Tehniskās universitātes Materiālzinātnes un lietiškāà kīmijas fakultātes Silikātu materiālu institūta vadošais pētnieks. V. Švinka ir vairāk kā 100 publikāciju un 17 patentu autors kīmijas inženierzinātnes silikātu materiālu un tehniskās keramikas nozarēs. V. Švinka ir Vācijas keramikas biedrības un Latvijas Materiālu pētīšanas biedrību biedrs, promocijas padomes P-02 loceklis un LZP eksperts.

Telefons + 37167615560

E-pasts: visvaldis.svinka@rtu.lv

Ruta Švinka, Dr. sc. ing., asociētā profesore un Rīgas Tehniskās universitātes Materiālzinātnes un lietišḳās k̦īmijas fakultātes Silikātu materiālu institūta vadošā pētniece. R. Švinka ir vairāk kā 100 publikāciju un 6 Latvijas patentu autore ksīmijas inženierzinātnes silikātu materiālu un tehniskās keramikas nozarēs. R. Švinka ir Amerikas keramikas biedrības biedre, Latvijas Materiālu pētīšanas biedrības biedre un valdes locekle, LZP eksperte.

Telefons +37167615560

E-pasts: ruta.svinka@rtu.lv

ORCID iD: 0000-0002-9926-3956

Ruta Svinka, Visvaldis Svinka.

\section{Highly Porous Oxide Ceramics.}

Keywords: aluminium oxide, zirconium oxide, titanium oxide, kaolin, talcum, cordierite, nanopowders, thermal insulation, thermal shock resistance.

Investigations of highly porous high temperature ceramic produced by slip casting from concentrated suspensions of raw materials were carried out in the Institute of Silicate Materials since 2004. Pores form due to chemical reaction of metallic aluminium powder with water in basic medium with $\mathrm{pH}$ 9.5-10.8. Using this method emission of carbon oxide that usually accompanies fabrication of porous ceramics is avoided. The following investigations in high temperature oxide systems have been carried out since 2007:

- zirconia containing materials - promotion work by Gerda Bula "Zircon oxide containing high temperature foam ceramic", 2008;

- corundum-mullite materials - promotion work by Ludmila MahnickaGoremikina "Influence of synthesis conditions and additives on the structure and properties of porous high temperature ceramics", 2015; 
- alumina materials with various additives - promotion work by Ieva Zake-Tiluga "The effect of mullite-forming additives on the properties of porous alumina ceramics", 2015;

- titania containing corundum-mullite materials;

- cordierite ceramic materials.

The goals of these investigations were to obtain of high temperature insulating materials and ceramic filters for filtration of hot and aggressive liquids. Properties of ceramics, such as dependence of thermal conductivity on the temperature and thermal shock durability, were determined. 